\title{
Linking Oxidative Stress and Proteinopathy in Alzheimer's Disease
}

\author{
Chanchal Sharma ${ }^{1,2}$ and Sang Ryong Kim ${ }^{1,2,3, *(\mathbb{D})}$ \\ 1 School of Life Sciences, Kyungpook National University, Daegu 41566, Korea; chanchalmrt@gmail.com \\ 2 BK21 FOUR KNU Creative BioResearch Group, Kyungpook National University, Daegu 41566, Korea \\ 3 Brain Science and Engineering Institute, Kyungpook National University, Daegu 41944, Korea \\ * Correspondence: srk75@knu.ac.kr; Tel.: +82-53-950-7362; Fax: +82-53-943-2762
}

Citation: Sharma, C.; Kim, S.R.

Linking Oxidative Stress and

Proteinopathy in Alzheimer's

Disease. Antioxidants 2021, 10, 1231.

https://doi.org/10.3390/

antiox10081231

Academic Editors: Eugenio Barone and Andres Trostchansky

Received: 8 July 2021

Accepted: 28 July 2021

Published: 30 July 2021

Publisher's Note: MDPI stays neutral with regard to jurisdictional claims in published maps and institutional affiliations.

Copyright: (c) 2021 by the authors. Licensee MDPI, Basel, Switzerland. This article is an open access article distributed under the terms and conditions of the Creative Commons Attribution (CC BY) license (https:// creativecommons.org/licenses/by/ $4.0 /)$.

\begin{abstract}
Proteinopathy and excessive production of reactive oxygen species (ROS), which are the principal features observed in the Alzheimer's disease (AD) brain, contribute to neuronal toxicity. $\beta$-amyloid and tau are the primary proteins responsible for the proteinopathy (amyloidopathy and tauopathy, respectively) in $\mathrm{AD}$, which depends on ROS production; these aggregates can also generate ROS. These mechanisms work in concert and reinforce each other to drive the pathology observed in the aging brain, which primarily involves oxidative stress (OS). This, in turn, triggers neurodegeneration due to the subsequent loss of synapses and neurons. Understanding these interactions may thus aid in the identification of potential neuroprotective therapies that could be clinically useful. Here, we review the role of $\beta$-amyloid and tau in the activation of ROS production. We then further discuss how free radicals can influence structural changes in key toxic intermediates and describe the putative mechanisms by which OS and oligomers cause neuronal death.
\end{abstract}

Keywords: proteinopathy; reactive oxygen species; Alzheimer's disease; amyloidopathy; tauopathy; oxidative stress

\section{Introduction}

Reactive oxygen species (ROS) result from normal daily cellular metabolism. Research conducted in the last two decades has clarified the role of ROS as secondary signaling molecules that regulate various biological and physiological processes, including proliferation, host defense, and gene expression [1,2]. Furthermore, earlier reports have also indicated the role of ROS as a signal transduction mechanism. This allows adaptation to changes in environmental nutrients and the oxidative environment [3]. In this respect, Kiley and Storz [4] have well defined, in the prokaryotes, mechanisms whereby ROS directly activates transcription factors (TFs) for stress adaptation. On the contrary, oxidative stress (OS) refers to elevated levels of intracellular ROS, such as superoxide anion $\left(\mathrm{O}_{2}{ }^{\bullet-}\right)$, hydroxyl radical $\left(\mathrm{OH}^{\bullet}\right)$, and non-radical molecules, such as hydrogen peroxide $\left(\mathrm{H}_{2} \mathrm{O}_{2}\right)$ and singlet oxygen $\left({ }^{1} \mathrm{O}_{2}\right)$, which further damage lipids, proteins, and DNA (Figure $1 \mathrm{~A}$ ). A high-energy exposure or electron transfer reaction leads to the production of highly reactive ROS, which is a stepwise reduction of molecular oxygen $\left(\mathrm{O}_{2}\right)$ as represented in equation (1). Moreover, ROS generation occurs at elevated rates in normal aging. It is an inevitable process in both acute and chronic pathophysiological conditions [5]. Thus, OS is usually the result of excessive ROS production, mitochondrial dysfunction, and an impaired antioxidant system, or a combination of these factors.

$$
\mathrm{O}_{2} \rightarrow \mathrm{O}_{2}^{\bullet-} \rightarrow \mathrm{H}_{2} \mathrm{O}_{2} \rightarrow \mathrm{OH}^{\bullet} \rightarrow \mathrm{H}_{2} \mathrm{O}
$$




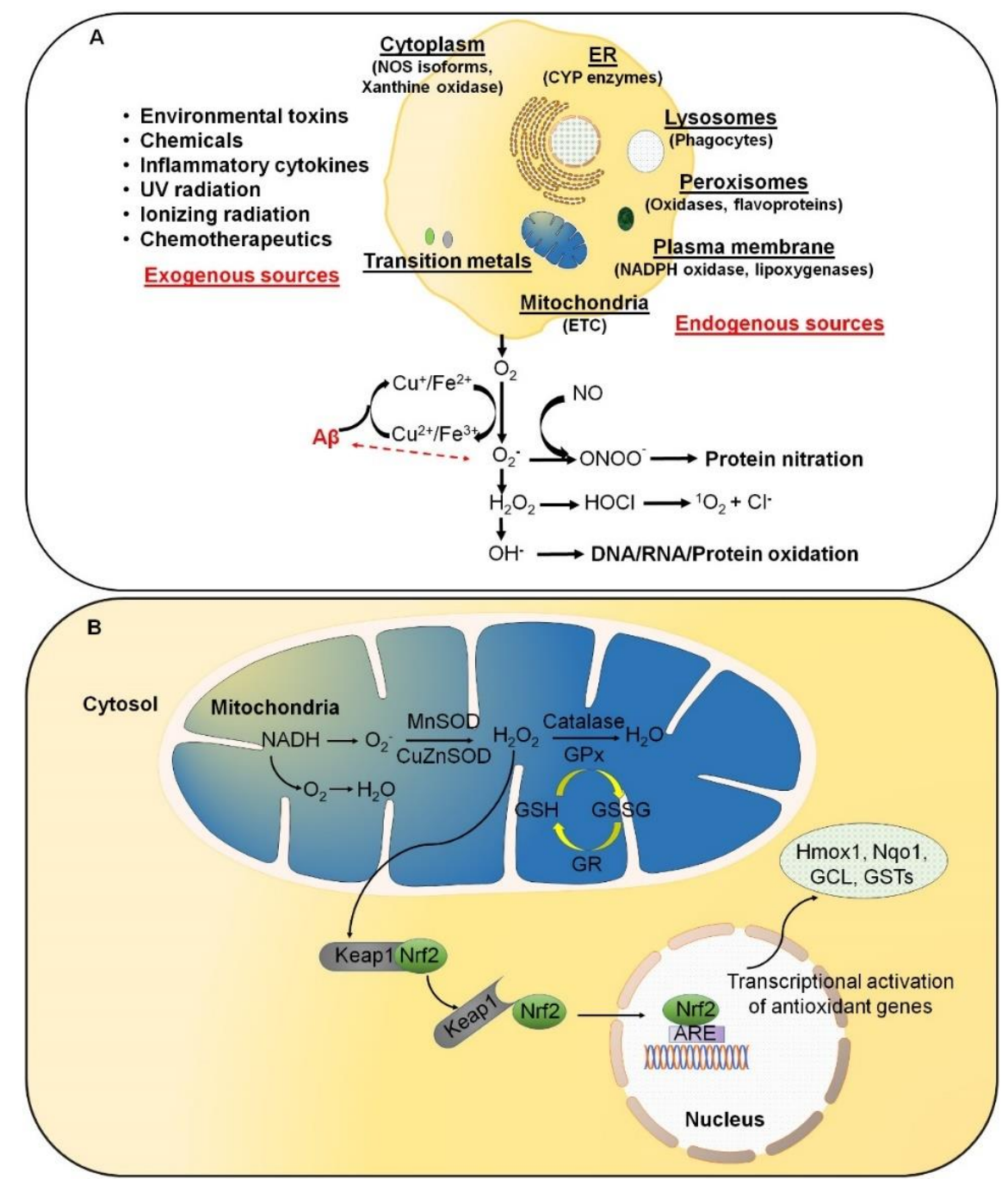

Figure 1. Excessive reactive oxygen species (ROS) are likely involved in the initiation and/or amplification of oxidative stress during the onset and progression of Alzheimer's disease (AD). (A) ROS can be produced from both endogenous and exogenous sources. The endogenous sources of ROS include different cellular organelles, such as mitochondria, peroxisomes, and the endoplasmic reticulum, where oxygen consumption is high. (B) Under physiological conditions, a cellular balance is established between ROS generation and clearance, and is maintained by several antioxidative defense mechanisms.

ROS are predominantly produced in mitochondria via mitochondrial enzymes. The electron transport chain (ETC) of mitochondria produces superoxide radicals at respiratory complexes I and III of the oxidative phosphorylation (OXPHOS) pathway through the single-electron leak [2,6]. Nevertheless, the rate of production of ROS in complex I is much less than the Flavin-dependent enzymes in the mitochondrial matrix [7]. Amongst various intracellular antioxidant enzymes, five have been mainly discussed in physiological conditions, i.e., (i) $\mathrm{Cu} / \mathrm{Zn}$-superoxide dismutase (Cu/Zn-SOD, SOD1) in the cytosol, (ii) manganese superoxide dismutase (Mn-SOD, SOD2) in the mitochondrial matrix, (iii) catalase (CAT), (iv) glutathione peroxidase (GPx), and (v) glutathione reductase. In Figure $1 \mathrm{~B}$, SOD converts superoxide to $\mathrm{O}_{2}$ and $\mathrm{H}_{2} \mathrm{O}_{2}$, whereas CAT and GPx convert $\mathrm{H}_{2} \mathrm{O}_{2}$ into $\mathrm{H}_{2} \mathrm{O}$ and $\mathrm{O}_{2}$. Along with the primary antioxidant defense against ROS, secondary antioxidant and cellular detoxification programs are mainly regulated by NF-E2-related factor 2 (Nrf2) and Kelch-like ECH-associated protein 1 (Keap1). Under normal conditions, Nrf2 is retained in the cytoplasm by the actin-binding protein Keap1; a substrate adaptor protein 
for the Cullin3-containing E3-ligase complex, which targets Nrf2 for ubiquitination and degradation by the proteasome [8]. Keap1 is redox sensitive since this protein can be modified by different oxidants and electrophiles [9]. OS abrogates the Keap1-mediated degradation of Nrf2, which in turn accumulates in the nucleus [10]. It heterodimerizes with a small musculoaponeurotic fibrosarcoma (Maf) protein on antioxidant response elements (AREs). Nrf2, along with ARE, further stimulates the expression of a wide array of phase II antioxidant enzymes, which includes $\mathrm{NAD}(\mathrm{P}) \mathrm{H}$ quinone oxidoreductase 1 (Nqo1), heme oxygenase 1 (Hmox1), glutamate-cysteine ligase, and glutathione $\mathrm{S}$ transferases (GSTs) [10-12]. In addition, Nrf2 also contributes to cellular proteostasis by regulating the expression of molecular chaperones and various proteasomal subunits [13-15]. Apart from antioxidant enzymes, small molecular weight and nonenzymatic antioxidants, such as vitamins, carotenoids, thiol antioxidants, and natural flavonoids, also protect intracellular components against ROS [16].

Deposition and spreading of aggregated proteins are the main characteristics of sporadic (s) and familial (f) forms of various neurodegenerative disorders, such as AD. This, in turn, results in excessive ROS production leading to OS, chronic neuroinflammation, and mitochondrial dysfunction, which altogether cause neuronal loss [17] and protein misfolding [18]. ROS-induced protein misfolding/unfolding can result in gain/loss-offunction. The protein modification of the oxidized proteins is insufficient to achieve their actual shape, impacting stability, activity, and/or function $[19,20]$. Several lines of evidence suggest that elevated ROS production initiates toxic amyloid beta precursor protein (APP) processing and thereby triggers amyloid-beta $(A \beta)$ generation [21,22]. These elevations in ROS are the results of protein aggregation and corresponding neuronal damage, which in turn activates disease-associated microglia via damage-associated molecular patterns [23]. These ROS are primarily generated via NADPH oxidase 2, which is well associated with DAMP signaling, inflammation, and amyloid plaque deposition [23]. Additionally, ROS generated from mitochondria helps in the propagation of immune activation, leading to excessive $\mathrm{OS}$ and neurodegeneration. Interestingly, recent studies on postmortem AD brains and AD transgenic mice have shown that $A \beta$ and APP are found in mitochondrial membranes to block protein transport and disrupt the ETC with final, irreversible cell damage [24]. Moreover, these disruptions are further exacerbated by a defective repair system. Tamagno and colleagues reported that OS resulting from hydroxynonenal (HNE) or $\mathrm{H}_{2} \mathrm{O}_{2}$ leads to enhanced $\mathrm{A} \beta$ production in different cell models [21]. In addition, HNE also modifies the $\gamma$-secretase substrate receptor nicastrin, which leads to enhanced binding of the $\gamma$-secretase substrate APP and likely results in elevated A $\beta$ generation [22]. Moreover, neurons contain a high amount of polyunsaturated fatty acids (PUFAs) that can interact with ROS, leading to a self-propagating cascade of lipid peroxidation and molecular destruction [25]. Products of lipid peroxidation have also been shown to be elevated in blood samples and brains of AD patients at autopsy [26,27]. Both nuclear and mitochondrial DNA and RNA also exhibit oxidative damage in the AD brain [28-30]. Hence, understanding oxidative balance is regarded as an important event in understanding $\mathrm{AD}$ pathogenesis. OS might increase the aggregation and production of $A \beta$ and assist polymerization and tau phosphorylation via the creation of a vicious cycle that stimulates the progression and even initiation of AD. Keeping this in mind, in this review, we sought to analyze the myriad interactions between oxygen radicals and toxic protein oligomers in the context of $\mathrm{AD}$ to understand their importance in disease pathogenesis. Furthermore, we also discuss the role of microbiota in altering redox balance and its consequences concerning $\mathrm{A} \beta$ production and tau hyperphosphorylation.

\section{Markers of Oxidative Stress}

ROS are oxygen-containing molecules that are more chemically reactive than $\mathrm{O}_{2}$ and, therefore, can damage cellular macromolecules. For example, ROS can react with nucleic acids (NA) by attacking nitrogenous bases and the sugar-phosphate backbone. Further, these can evoke single- and double-stranded DNA breaks, affecting the protein-coding 
region of mtDNA and influencing OXPHOS [31,32]. mtDNA mutations can cause disturbances in the respiratory chain, and as a result, it loses control over ROS production [1]. In addition, the modification in core DNA repair genes can result in an impaired recognition system and an inefficient repair of DNA damage, which in turn can accelerate aging and leads to age-related disruptions in cellular and tissue functions. This also results in the accumulation of ROS, which increases with age and intensifies OS. This elevation in OS damages mtDNA, leading to apoptosis, inhibition of mitochondrial respiratory chain transition, and increased mitochondrial membrane permeability in the absence of sufficient antioxidant capacity [5]. Thus, pro-oxidative/antioxidative cellular imbalance between ROS production and the ability of the defense mechanisms of biological systems to eliminate ROS-mediated cellular stress disturbances results in a vicious cycle, since the OS reciprocally aggravates ROS production. ROS have also been reported to attack structural and enzymatic proteins via oxidation of residual amino acids, prosthetic groups, formation of cross-links and protein aggregates, and proteolysis [32]. Lipid peroxidation (auto-oxidation) is a process in which PUFAs are oxidized due to several double bonds in their structure. This process involves producing peroxides (chemical compounds in which a single covalent bond links two oxygen atoms), ROS, and other reactive organic free radicals. Several markers of oxidative damage have been defined, including the following: 8-hydroxy-2-deoxyguanosine (8-OHdG) and 8-hydroxyguanosine, markers of oxidative DNA damage; 8-hydroxyguanine, a marker of RNA oxidation; protein carbonyls and nitrotyrosine, markers of protein oxidation; and malondialdehyde (MDA), thiobarbituricacid-reactive substances, 4-hydroxy-2-nonenal (4-HNE), acrolein, isoprostanes, and neuroprostanes, markers of lipid peroxidation $[5,32,33]$. Moreover, ROS and aging have also been linked to the promotion and accumulation of advanced glycation end products (AGEs). AGEs are insoluble in detergents, protease-resistant, and non-degradable protein, lipid, or NA aggregates generated by non-enzymatic glycation or glycoxidation after exposure to aldose sugar. AGEs have been reported to impair normal cellular/tissue functions directly or indirectly through the AGE/RAGE pathway after binding to specific receptors for advanced glycation end products (RAGEs) [34]. Due to synergism with OS, the production of AGEs is promoted by OS, which eventually leads to ROS generation.

Furthermore, AGEs have been found to accumulate in numerous tissues throughout physiological aging, which leads to OS since the ability to respond to OS reduces with age. Due to this, many proteins lose their function, including those involved in gene transcription regulation $[32,33]$. Thus, AGEs serve not only as proinflammatory molecules but also as potent neurotoxins [35]. Protein glycation begins as a nonenzymatic process with a free amino acid group capable of producing a labile Schiff base. The process thus takes place along with the unconstrained condensation of aldehyde or ketone groups reportedly present in sugars. Furthermore, the phenomenon mentioned above also agrees with Maillard's classical reaction in 1912 [36,37]. Subsequently, a series of reactions occur that result in the generation of AGEs containing irreversibly cross-linked heterogeneous protein aggregates.

\section{Linking OS and Proteinopathy in AD}

The molecular associations of proteinopathy and proteotoxicity with OS are varied and complicated. Indeed, considerable evidence suggests that OS occurs before the appearance of symptoms in $\mathrm{AD}$ and that oxidative damage is detected not only in the vulnerable brain regions [38] but also in peripheral areas [36,38-40]. A reduction in the protein's breakdown rate due to impaired proteasomal or lysosomal pathway or transcriptional activation or rapid translation of a specific mRNA may result in the accumulation of a specific hazardous protein [41-43]. In some circumstances, the mutant gene produces an abnormal protein product that is not cleared by the protein degradation machinery, causing it to accumulate. A similar event may occur in post-translationally modified proteins due to changes in the internal milieu of the cell, such as those observed in the redox status and kinase activity $[42,43]$. Excess accumulation of wild-type (WT) or mutant protein can precede 
various conformational alterations, e.g., helix to $\beta$-strand, facilitating oligomerization and self-aggregation. Heat shock proteins (HSP), such as HSP40, HSP70, HSP90, and other chaperones and co-chaperones, usually prevent misfolding of intracellular proteins. However, excessive accumulation, redox modifications, and/or mutations of such proteins may overwhelm this system and alter these chaperones' expression [44,45]. The term proteotoxicity refers to the toxic effect of these protein aggregates on the various functions of cell organelles. ROS-responsive TFs can alter genes that encode such toxic proteins or enzymes involved in their production, processing, or degradation [46]. Furthermore, the proteasomal system, particularly the $26 \mathrm{~S}$ proteasome, is responsible for degrading toxic protein aggregates and can be directly inactivated by OS to varying degrees. The in-depth mechanism of how ROS-mediated regulation of $26 \mathrm{~S}$ proteasomal degradation occurs is currently being researched and clarified $[47,48]$. Furthermore, ROS may also influence the lysosomal clearance of toxic proteins, resulting in autophagy failure. The former is known to have an intricate relationship with autophagy, an intracellular degradation system [48]. ROS may also potentiate the oligomerization of proteins, such as $A \beta$, which interacts with transition metals (TM) such as iron $(\mathrm{Fe})$, copper $(\mathrm{Cu})$, zinc $(\mathrm{Zn})$, etc., or other components capable of generating additional ROS (2-3). Likewise, proteotoxicity and mitochondrial dysfunction are also intertwined. Several studies conducted using isolated mitochondria, in vitro cell cultures, and postmortem brain samples showed that all forms of $\mathrm{A} \beta$ (monomer, oligomerized, or aggregated) cause a wide-ranging mitochondrial functional impairment which includes a reduction in bioenergetics, alteration in fusion/fission cycle, and impaired mitophagy $[49,50]$. Thus, proteotoxicity-induced mitochondrial dysfunction results in excess ROS production and triggers cell death pathways.

$$
\begin{gathered}
\mathrm{A} \beta+\mathrm{TM} \rightarrow \mathrm{A} \beta-\mathrm{TM} \\
\mathrm{A} \beta-\mathrm{TM} \rightarrow \mathrm{TM}-\mathrm{A} \beta^{+\bullet}
\end{gathered}
$$

\subsection{Oxidative Stress and A $\beta$ Proteinopathy}

APP is a type I membrane protein that is synthesized and modified post-translationally in the endoplasmic reticulum (ER) and Golgi apparatus (GA) [51-53]. APP is further transported to the cell surface by a mechanism analogous to those used by other integral transmembrane proteins [51-53]. The metabolism of APP follows either a non-amyloidogenic pathway through $\alpha$-secretase cleavage or an amyloidogenic pathway through cleavage mediated by $\beta$-site APP cleaving enzyme 1 (BACE1) [51-53]. Non-amyloidogenic processing predominantly occurs at the cell surface where $\alpha$-secretase cleaves APP within the $\mathrm{A} \beta$ domain and generates a secreted large amino fragment ((s)APP $\alpha)$ and a small carboxyl (C)-terminal fragment ( $\alpha$ CTF: C83) [51-53]. On the contrary, during the amyloidogenic processing, which takes place in the endosomes, BACE1 processes APP to a soluble $\beta$-cleaved ectodomain (sAPP $\beta$ ) and a C-terminal fragment ( $\beta$ CTF: C99) [51-53]. This cleavage of APP results in the generation of toxic proteins termed A $\beta$ peptides (A $\beta 42$ and $A \beta 40$ peptides), deposited as amyloid and neuritic plaques in extracellular brain regions [51-53]. Recent studies have demonstrated that APP is internalized through lipid rafts and clathrin-mediated endocytosis [53]. However, BACE1 is internalized by ADP ribosylation factor 6 endocytosis and is then sorted into early endosomes [53]. Further, the $\gamma$-secretase complex is responsible for the cleavage of $\beta C T F$ (cleaved product of BACE1), which generates $A \beta$. Thus, generated $A \beta$ is finally released into the extracellular space by fusing multi-vesicular bodies with the plasma membrane (PM) or is degraded via an endolysosomal pathway [52-58].

The expression, processing, and intracellular protein trafficking of APP and A $\beta$ peptides reportedly occur in the trans-Golgi network, endosomes, and PM and are welldefined phenomena $[57,58]$. Importantly, endosomal changes, which are early events in $\mathrm{AD}$ progression, result in intra-neuronal $\mathrm{A} \beta$ accumulation and are correlated with redox imbalance, OS, synaptic dysfunction, cognitive impairment, and accelerated aging. During self-aggregation on neuronal membranes, a toxic aldehyde known as 4-HNE is 
produced, which causes lipid peroxidation and can cause ion-motive ATPases, glucose transporters, and glutamate transporters to malfunction [57-59]. In turn, $A \beta$ promotes synaptic membrane depolarization, excessive calcium influx, and mitochondrial damage, impairing cells' capacity to carry out normal physiological functions $[60,61]$. Thus, based on postmortem data and experimental studies carried out using cell lines, primary culture of hippocampal neurons, and transgenic animal models, it has been prominently suggested that $A \beta$ peptide oligomers can interact with numerous astrocytic, microglial, and neuronal synaptic proteins, including $\alpha 7$ - acetylcholine receptors (AChRs) and $\mathrm{N}$ methyl-D-aspartate receptors (NMDARs); this, in turn, triggers a series of toxic synaptic events [58-61]. These events include abnormal activation of NMDARs (particularly NR2Bcontaining extrasynaptic NMDARs), increased neuronal calcium influx, calcium-dependent activation of calcineurin/PP2B, and its downstream signal transduction pathways involving cofilin, glycogen synthase kinase 2 beta (GSK-3 $\beta$ ), cAMP response element-binding protein (CREB), and myocyte enhancer factor 2 (MEF2) [58-61]. This results in aberrant redox reactions and severing/depolymerizing F-actin, tau hyperphosphorylation, and endocytosis of $\alpha$-amino-3-hydroxy-5-methyl-4-isoxazolepropionic acid receptors (AMPARs), which eventually leads to synaptic dysfunction and cognitive impairment and triggers the process of neurodegeneration in $\mathrm{AD}$ [56-62]. The inactivation of key proteins can lead to serious consequences in vital metabolic pathways. For instance, oxidized proteins can be harmful to membrane integrity. They may change the sensitivity of enzymes such as glutamine synthetase and creatine kinase, which are essential for brain function, to oxidative alterations $[57,61,62]$. This evidence suggests that $A \beta$ trafficking pathways may be a therapeutic target through which disease manifestations may be improved [56-62].

$A \beta$ toxicity has been demonstrated in vitro [63]. When placed in a physiological solution, $A \beta$ precipitates into fibrils and generates free radicals. Casley et al. (2002) investigated the connection between $A \beta$ and mitochondrial function using a cell-culture system [64]. They revealed that $A \beta$ directly induces mitochondrial oxidative damage due to the generation of free radicals [64]. To this aim, they isolated rat mitochondria and incubated them with $A \beta$ alone and with $A \beta$ and nitric oxide (NO) together. They further measured the levels of tricarboxylic acid (TCA) enzyme complexes [65] and a-ketoglutarate dehydrogenase and pyruvate dehydrogenase activities [64]. Their findings revealed that $A \beta$ significantly reduces mitochondrial respiration. Additionally, $A \beta$, together with $N O$, can further diminish mitochondrial respiration. In addition, they found that $A \beta$ also inhibits the activities of cytochrome oxidase, a-ketoglutarate dehydrogenase, and pyruvate dehydrogenase [66,67]. Similarly, Kim et al. (2002) also showed that the addition of A $\beta$ to isolated mitochondria from brain tissues taken directly from rats induces the release of cytochrome $\mathrm{c}$ and mitochondrial swelling [67]. These findings from the study by Kim et al. (2002) suggest that in AD, A $\beta$ may accumulate intracellularly via abnormal APP processing. Its accumulation may exert neurotoxicity by interacting with mitochondria and causing oxidative damage apoptosis [67]. Furthermore, Tamagno et al. (2002) reported that the OS product 4-HNE could modulate BACE1. The NT2 neurons, when exposed to ascorbate $/ \mathrm{FeSO}_{4}$ and $\mathrm{H}_{2} \mathrm{O}_{2} / \mathrm{FeSO}_{4}$, resulted in a significant generation of 4-HNE. They also reported that an increase in the levels of 4-HNE was well correlated with an increase in BACE1 protein levels and was accompanied by a proportional increase in carboxy-terminal fragments of APP [21,22]. They confirmed their findings by pretreating NT2 neurons with alpha-tocopherol, which is reported to prevent the formation of aldehydic end products of lipid peroxidation, including 4-HNE. These findings of Tamagno et al. (2002) support the hypothesis that OS and $A \beta$ production are strictly interrelated events and that BACE1 inhibition may have a synergic therapeutic effect with antioxidant compounds [21,22].

In $\mathrm{AD}$, the presence of elevated extracellular $\mathrm{A} \beta$ levels at potential sites of lipid peroxidation only serves to elevate the risk of oxidative damage. Compellingly, compared with age-matched controls, in areas such as the hippocampus, where AD pathology is concentrated, higher levels of 4-HNE in AD patients are observed [68]. Reports investigating patients with mild cognitive impairment confirm an increase in OS due to high levels 
of brain 4-HNE, an early event in AD pathogenesis [68-70]. Supporting this notion, OS markers, including lipid peroxidation, have been shown to precede and be accompanied by $\mathrm{A} \beta$ pathology in AD transgenic mouse models [71]. Recently, a study by Gwon and colleagues explained how OS could induce $\mathrm{A} \beta 42$ production via 4-HNE- or $\mathrm{Fe}^{2+}$-mediated modification of $\gamma$-secretase activity [72]. Using cultured human neuroblastoma (SH-SY5Y) cells and a luciferase reporter assay, they demonstrated that exogenous addition of 4-HNE or $\mathrm{Fe}^{2+}$ enhanced $\gamma$-secretase activity results in an increase in the $\mathrm{A} \beta 42 / \mathrm{A} \beta 40$ ratio $[72,73]$. They further identified 4-HNE-mediated modification of nicastrin, a component of mature $\gamma$-secretase complexes, as the possible reason for the increase observed in the A $\beta 42 / A \beta 40$ ratio. This could be because nicastrin liberates $A \beta$ from APP, which may amplify amyloidogenic processing of APP via increased 4-HNE activation of $\gamma$-secretase activity [72,73]. However, the application of reduced glutathione (GSH) analog or the $\gamma$-secretase inhibitor (GSI) L685,458 could suppress the increase in $\gamma$-secretase activity [72,73]. Altogether, a positive feedback system might exist in which $A \beta$ not only participates but also promotes lipid peroxidation, which in turn is facilitated by increases in extraneuronal $\mathrm{Fe}^{2+}[72,73]$.

$\mathrm{A} \beta$ has been reported to generate $\mathrm{H}_{2} \mathrm{O}_{2}$, a key ROS, from $\mathrm{O}_{2}$ through electron transfer interactions involving bound redox-active $\mathrm{Cu}^{2+}$ and $\mathrm{Fe}^{3+}[73,74] . \mathrm{H}_{2} \mathrm{O}_{2}$ is readily converted into an aggressive $\mathrm{OH}$ radical by Fenton chemistry (4). These two types of ROS have been reported to be responsible for the early oxidative damage seen in AD. Some studies have shown that the levels of $\mathrm{H}_{2} \mathrm{O}_{2}$ generated by $\mathrm{A} \beta$ can be enhanced by co-incubation of the peptide with a reducing substrate, which becomes oxidized in the process [73-75]. For instance, using cholesterol as a reducing substrate, the resulting oxidation product will be $7 \beta$-hydroxycholesterol, proapoptotic and neurotoxic even at nanomolar concentrations. Thus, this molecule can also contribute to oxidative brain damage in $\mathrm{AD}$ [75].

$$
\mathrm{H}_{2} \mathrm{O}_{2}+\mathrm{Fe}^{2+} \rightarrow \mathrm{OH}^{\bullet}+\mathrm{HO}^{-}+\mathrm{Fe}^{3+}
$$

AGEs are regarded as chemical molecules that can be cross-linked to long-lived proteins [76,77]. In $\mathrm{AD}$, enhanced oxidation of glycated proteins (i.e., glycoxidation) results in the extracellular accumulation of AGEs [78]. This has been confirmed in classic and primitive plaques observed in different cortical areas and senile plaques [78]. In vitro experiments conducted by Li and Dickson using double immunohistochemistry revealed AGE's colocalization with apolipoprotein E (ApoE) [79]. They examined the binding of ApoE variants to AGE in the presence of bovine serum albumin and found that the dimeric form of ApoE has more binding specificity towards AGE. Furthermore, the results also suggested a three-fold higher binding activity between AGE and ApoE4 compared to binding activity between AGE and ApoE3, which signifies the pathogenic risk associated with ApoE4 in the case of fAD. AGE formation is reported to accelerate the formation of $\mathrm{A} \beta$ monomer to oligomeric forms [80]. Lines of evidence have shown prominent binding between $A \beta$ and $A p o E 4$, resulting in $A \beta$ fibril formation and many subsequent pathways [79-82]. Recently, a cohort study involving the Dutch population revealed a higher association between AGEs and carriers of ApoE4 in progressive dementia [83].

Abnormal $\mathrm{Cu}, \mathrm{Zn}$, and Fe levels have been reported in the hippocampus and amygdala, along with severe histopathological changes in patients with $\mathrm{AD}$ [84-86]. A $\beta$ generates ROS through different redox activities by binding to $\mathrm{Cu}$ or $\mathrm{Fe}$ (5-7) [74,86-89]. $\mathrm{Cu}^{2+}$ is reportedly found bound to several enzymes, such as SOD, cytochrome c oxidase, ceruloplasmin, and tyrosinase, which are involved in critical neuronal and non-neuronal cellular biochemical pathways. For instance, astrocytes can store and export $\mathrm{Cu}^{2+}$ to neurons. However, excess $\mathrm{Cu}^{2+}$ in astrocytes results in binding of $\mathrm{Cu}^{2+}$ to $\mathrm{A} \beta$ to form a cuproenzyme-like complex, which can transfer an electron to $\mathrm{Cu}^{2+}$ to convert $\mathrm{Cu}^{2+}$ to $\mathrm{Cu}^{+}$, thus forming the $\mathrm{A} \beta$ radical $\left(\mathrm{A} \beta^{+\bullet}\right)[74,85-90]$. Furthermore, $\mathrm{Cu}^{+}$can donate two electrons to $\mathrm{O}_{2}$ to generate $\mathrm{H}_{2} \mathrm{O}_{2}$ and produce $\mathrm{OH}$ radicals (Fenton-type reaction) $[74,88,89] . \mathrm{Fe}^{2+}$ is highly reactive, and excess of this metal ion often overproduces reactive chemical species $\left(\mathrm{OH}^{\bullet}\right)[74,91]$. Fe accumulation is prominent in both in vitro and in vivo $\mathrm{AD}$ models that involve neuritic plaques, which further result in OS [92]. For instance, in SH-SY5Y cells overexpressing the Swedish 
mutant form of human APP, the intracellular Fe levels are significantly elevated along with increased OS [74]. The binding of Fe to $\mathrm{A} \beta$ results in the reduction of $\mathrm{Fe}^{3+}$ to $\mathrm{Fe}^{2+}$ and the generation of $\mathrm{H}_{2} \mathrm{O}_{2}[90,91]$. As a critical component of amyloid plaques and cerebrovascular amyloidosis, $\mathrm{Zn}$ has also been reported to be involved in $\mathrm{A} \beta$ accumulation and ROS production in triple-transgenic mice [93]. It has been suggested that $\mathrm{OH}^{\bullet}$ formation further damages biomolecules, such as lipids, proteins, and NA, due to the ability of $\mathrm{OH}^{\bullet}$ to catalyze specific reactions, including hydrogen abstraction, addition reactions, and oxidation reactions in AD. These findings demonstrate that the interactions between $\mathrm{A} \beta$ and metals also produce ROS.

$$
\begin{array}{r}
\mathrm{Fe}^{3+} / \mathrm{Cu}^{2+}+\mathrm{O}_{2}^{\bullet-} \rightarrow \mathrm{Fe}^{2+} / \mathrm{Cu}^{+}+\mathrm{O}_{2} \mathrm{Fe}^{3+} / \mathrm{Cu}^{+}+\mathrm{O}_{2}^{\bullet-} \rightarrow \mathrm{Fe}^{2+} / \mathrm{Cu}^{+}+\mathrm{O}_{2} \\
\mathrm{Fe}^{2+} / \mathrm{Cu}^{+}+\mathrm{H}_{2} \mathrm{O}_{2} \rightarrow \mathrm{Fe}^{3+} / \mathrm{Cu}^{2+}+\mathrm{OH}^{\bullet}+\mathrm{OH}_{-} \mathrm{Fe}^{2+} / \mathrm{Cu}^{+}+\mathrm{H}_{2} \mathrm{O}_{2} \rightarrow \mathrm{Fe}^{3+} / \mathrm{Cu}^{2+}+\mathrm{OH}^{\bullet}+\mathrm{OH} \\
\mathrm{O}_{2}^{\bullet-} \rightarrow \mathrm{H}_{2} \mathrm{O}_{2} \rightarrow \mathrm{O}_{2}+\mathrm{OH}^{\bullet}+\mathrm{OH}_{-} \mathrm{O}_{2}^{\bullet}+\mathrm{H}_{2} \mathrm{O}_{2} \rightarrow \mathrm{O}_{2}+\mathrm{OH}^{\bullet}+\mathrm{OH}
\end{array}
$$

\subsection{Oxidative Stress and Tau Proteinopathy}

Besides $A \beta$ proteinopathy, another prominent feature of AD pathogenesis is the accumulation of phosphorylated tau protein within neurons, known as neurofibrillary tangles (NFTs). These tau neurites also contribute to synaptic dysfunction and axonal degeneration [94]. Tau usually plays a significant role by stabilizing neuronal microtubules [95]. However, in AD, abnormal phosphorylation facilitates disassociation from the microtubule, resulting in the loss of function [96]. The change prompts self-assembly into highly toxic soluble oligomers, forming larger fibrils and tangles deposited within neurons $[95,96]$. Tau aggregates exhibit cell-cell transfer, which leads to seeding and further aggregation, supporting the concept of region to region spreading of phosphorylated tau in AD [97]. These plaques and NFTs are primarily deposited in brain regions, such as the hippocampus, amygdala, entorhinal cortex, and basal forebrain, which reportedly play an essential role in memory, learning, and emotional behaviors; plaques and NFTs reduce the number of synapses in these areas $[55,98,99]$. It has been suggested that an imbalance between kinases and phosphatases leads to aberrant tau hyperphosphorylation. As of now, nearly 28 protein kinases are known to be responsible for tau phosphorylation [100]. Furthermore, $\mathrm{A} \beta$ aggregates could be a component in a set of molecular events that lead to tau hyperphosphorylation [101,102]. For example, to favor the NFT formation, 4-HNE can induce alterations in tau protein structure which facilitates the participation of $A \beta$-induced OS in AD pathogenesis.

According to the published experiments and reports, OS is well associated with tau pathology. Moreover, cells with overexpressing tau protein are more vulnerable to the OS, likely caused by peroxisome depletion $[103,104]$. Tau protein can effectively induce ROS production in mitochondria. For instance, hippocampal tau phosphorylation in tau transgenic mice with the P301L mutation reportedly induces mitochondrial dysfunction, which results in $\mathrm{H}_{2} \mathrm{O}_{2}$ production, lipid peroxidation, and eventually neuronal loss [103-106]. Moreover, a reduction in cytoplasmic SOD1 or a deficit in mitochondrial SOD2 [107] increases tau phosphorylation in Tg2576 AD transgenic mice. Besides reducing nicotinamide adenine dinucleotide (NADH), ubiquinone oxidoreductase and mitochondrial dysfunction are also observed in the tau transgenic AD mouse model. This phenomenon has been well associated with elevated production of ROS, weakened synthesis of adenosine triphosphate (ATP), and mitochondrial respiration in aged animals [108].

Interestingly, P301S transgenic mouse brains showed enhanced OS and higher protein carbonyl levels in the cortical mitochondria. The relationship between tau pathology and OS was confirmed in P301L and P301S transgenic mouse models carrying the human tau gene with either the P301L or P301S mutation; these mice display accumulation of hyperphosphorylated tau, which causes neurodegeneration and the development of NFTs [109]. Tau, both directly and indirectly, influences mitochondrial function and mitochondrial transport along the neuronal axon, resulting in the reduction and impairment of mito- 
chondria at presynaptic terminals with obvious deleterious consequences $[110,111]$. In AD-induced brains, phosphorylated tau was discovered to engage with voltage-dependent anion channel 1 (VDAC1), causing mitochondrial dysfunction [112]. As observed in AD postmortem brains and rodent models, tau hyperphosphorylation reduces complex I activity. It further causes a reduction in ATP generation, elevation in OS, mitochondrial membrane potential $(\mathrm{mt} \Delta \Psi)$ dissipation, promotion of mitochondrial fission, and fragmentation [113]. Additionally, in a mouse model, mitochondrial stress was found to induce tau hyperphosphorylation [107]. These findings strongly suggest that tau pathology plays a significant role in mitochondrial dysfunction in AD.

Application of extracellular tau at different stages of aggregation to cortical co-cultures of neurons and astrocytes showed that only insoluble aggregates of tau could induce ROS production by activating nicotinamide adenine dinucleotide phosphate (NADPH) oxidase in a calcium-dependent manner [114]. The essential constituent of NFTs, the microtubuleassociated protein tau (MAP-tau), was revealed to be vital to the formation of intracellular AGEs [115]. On the contrary, MAP-tau can be glycated in vitro, which decreases its capacity to bind to microtubules. Moreover, MAP-tau in the tubulin-binding region isolated from AD brains is glycated, leading to $\beta$-sheet fibril formation $[116,117]$.

\section{Linking Microbiota with Oxidative Stress and AD}

Recently, several pieces of evidence link the role of microbiota in brain biology and aging, being an essential factor involved in various physiological processes via interactive symbiotic network system with host [118-123]. This interactive network between host and microbiota interconnects the gut track, epidermis, liver, and all other organs with the central nervous system, generally referred to as the microbiota-gut-brain axis $[124,125]$. The microbiota is composed mainly of bacteria that colonize all mucosal surfaces, with higher density in the gastrointestinal tract, approximately 100 trillion bacteria from nearly 1000 various bacterial species $[118,124]$, thereby influencing and triggering various events associated with aging disorders such as AD [118-120,124,126]. Recently, a line of evidence revealed an association of brain amyloidosis with pro-inflammatory gut bacteria in cognitively impaired patients [127] and various AD mouse models [128,129]. These findings strongly highlight the association of microbiota and amyloid pathogenesis in AD. However, these fields lack crucial in-depth information and require more exploration.

Physiological levels of OS have been generated in the microbiota, which can interfere with its composition and functionality [130]. Furthermore, interactions between microbemicrobe or host-microbiota may also impact the CNS redox balance by elevating ROS levels or impairing the antioxidant system or both [131,132]; hence, serving not only as a cause but also a consequence of increased levels of oxidative injury in CNS [131], thus adding a new dimension to the interplay between the gut microbiota and the brain. Moreover, the microbiota can also produce a considerable amount of CNS neurotransmitters, including dopamine, serotonin, and gamma-aminobutyric acid, that can modulate the local activity of the enteric nervous system and can correlate with their respective levels within the CNS, which in turn depends on the intestinal and BBB permeability [133]. The microbiota may also produce neurotoxic and potentially neurotoxic substances (such as lipopolysaccharides and amyloid proteins), which can also reach to CNS via the systemic circulation or the vagus nerve, promoting microglial activation and neuroinflammation, elevated ROS levels, and/or making neurons more susceptible to OS [133]. Therefore, gut microbes were considered plausible triggering factors for several neurodegenerative disorders, considering the proximity of enteric nervous system neurons to the intestinal lumen [134].

However, the production of amyloid proteins helps in the formation of bacterial biofilms by promoting the binding of bacterial cells with each other, thus providing resistance from physical or immune factor-mediated destruction [126]. However, in abnormal physiological conditions, bacterial amyloids may act as prion proteins and result in cross-seeding of amyloidogenic protein that elevates pathogenic $A \beta$ formation both 
in vitro and in vivo [126,135-138]. For instance, the interaction of cyanobacteria with synaptic receptors such as NMDA results in upregulation of $\beta$-N-methylamino-L-alanine (BMAA), an OS-inducing neurotoxin $[139,140]$, in AD brains. Furthermore, BMAA has been linked with protein misfolding and resulting inflammatory consequences in the $\mathrm{AD}$ mice model [139-141]. Numerous studies also suggested a link between activation of endogenous herpes simplex-1 (HSV-1) and amyloidogenesis in AD. This intimate relationship resulted in progressive neurodegeneration and cognitive impairment, contributing to $\mathrm{AD}$ pathogenesis [142-144]. A possible reason for this could be the alteration in gut dysbiosis, which results in increased gut barrier permeability, which in turn hyper activates the innate immune response that leads to systemic inflammation, thus impairing the blood-brain barrier [126], which results in neuronal injury, protein misfolding, and neurodegeneration leading to cognitive impairment [145]. In addition, overwhelmed microglial stimulation and NF- $\mathrm{kB}-$ mediated proinflammatory signaling and reactive oxidative and nitrosative stressors can result in neuronal and glial cell death, which can further impair phagocytosis, leading to the accumulation of A $\beta 42$ [146,147]. C/EBP $\beta$ /AEP signaling was activated in 3xTg mice 5xFAD mice due to gut dysbiosis, resulting in $A \beta$ aggregates, OS, and tau hyperphosphorylation [148].

Furthermore, reduction in the relative abundance of Proteobacteria and the low levels of Bifidobacteria can reduce beneficial short-chain fatty acids, leading to lipid peroxidation [149]. This, in turn, results in impaired APP processing and trafficking, thus impacting the production of $A \beta$. Studies conducted using germ-free mice have confirmed the impact of microbiota on microglia maturation, astrocyte activity, neuroinflammation, OS, protein misfolding, and cognitive impairment in AD pathogenesis [129]. Modifying the gut microbiota composition with food-based therapy or supplementing with probiotics may be helpful as a new preventive and therapeutic option in both in vitro and in vivo AD models and clinical trials [146,147,150-154].

\section{Antioxidants and AD}

It is now evident that $A \beta$ and tau pathologies are modulated by ROS and are also self-perpetuating concerning ROS formation [155]. Hence, strategies involving inhibition of $\mathrm{A} \beta$ oligomerization or decreasing ROS production through the design of multitargeted compounds, such as antioxidants, have resulted in several promising approaches currently being tested in clinical trials. Antioxidants are a broad and heterogeneous collection of chemicals that work by inhibiting the production, detoxification, or scavenging of oxidant species. According to a different criterion, antioxidants can be classified into four different classes based on their chemical structure: vitamins (e.g., ascorbic acid, $\alpha$ tocopherol, $\beta$-carotene, and retinol), synthetic compounds (e.g., butylated hydroxytoluene), natural compounds (e.g., plant-derived polyphenols), and inorganic compounds. Some antioxidants act as chain-breaking molecules, as they can prevent the propagation of or stop radical chain reactions (e.g., $\alpha$-tocopherol). On the contrary, antioxidants, such as Gpx and catalase, can detoxify $\mathrm{H}_{2} \mathrm{O}_{2}$. This chemical reaction serves a vital role in cell biology as $\mathrm{H}_{2} \mathrm{O}_{2}$ can produce $\mathrm{OH}$ radicals in the presence of transition metals such as $\mathrm{Fe}^{2+}$, for which there is no detoxification system [32].

Several antioxidant studies in AD models have also been reported, demonstrating that antioxidants consistently positively affect the animals' behavioral and amyloidotic phenotypes (Table 1). Vitamins are potent antioxidants that directly affect free radicals by reducing OS, inflammatory processes, and neuronal loss [156]. Vitamin A (retinol) is essential for neuronal formation and remains present in the nervous system across life. Along with $\beta$-carotene, vitamin A also protects regenerating neurons during the neurodegeneration process by preventing the development and aggregation of $A \beta$ plaques both ex vivo and in vivo. It may also prevent impaired cognition in $A D$ and improve memory performance and spatial learning in rodent models. Studies have shown that AD patients have lower vitamin $A$ and $\beta$-carotene compared with healthy individuals [156,157]. Early vitamin $E$ ( $\alpha$-tocopherol) supplementation significantly reduced $A \beta$ levels and deposition 
in the Tg2576 AD model [158]. The same therapeutic regimen prevents a surge in amyloidosis [158]. It improves cognitive function after experimental traumatic brain injury, a known risk factor for AD development in Tg2576 mice [159]. Curcumin, a popular antioxidant and anti-inflammatory substance found in curry spices, substantially decreases OS and amyloid pathology in the Tg2576 mouse model [160].

Furthermore, curcumin is a potent inhibitor of $A \beta$ fibrillization [161] and oligomerization [162] and promotes destabilization of pre-existing $A \beta$ deposits in both cell culture models and animal models of AD [160-162]. Curcumin and its derivatives also increase the uptake and clearance of $\mathrm{A} \beta$ by macrophages in $\mathrm{AD}$ patients [163]. Furthermore, using LLC-PK 1 and NRK-52E cells, Balogun and colleagues reported that curcumin upregulates $\mathrm{A} \beta$-induced SOD and catalase and can further activate Nrf2 by selectively binding to Keap1 [164]. Luteolin has also been associated with activating the Nrf2 pathway, which increases endogenous antioxidative gene expression in neuronal cells [165]. Melatonin, a drug with antioxidant properties, partially inhibits the expected time-dependent elevation in $A \beta$ levels, reduces the abnormal nitration of proteins, and increases the survival of Tg2576 mice [166]. Similarly, ferulic acid, rosmarinic acid, and nordihydroguaiaretic acid (NDGA) have also been reported to inhibit the fibrillization and/or oligomerization of $\mathrm{A} \beta$ into higher-order species in vitro [167-170].

The significant outcomes of these studies are reductions in $A \beta$ levels, phosphorylated tau, mitochondrial dysfunction, microglial activation, enhanced synaptic activity, and amelioration of cognitive decline. These results indicate that antioxidant treatment is beneficial in reducing and/or preventing AD progression. The findings also show that combination therapy positively impacts cognitive behavior and lowers AD pathology. The positive findings of these studies are promising. However, they warrant prospective studies (e.g., antioxidant treatment of elderly individuals without $A D$ ) and clinical trials (antioxidant treatment for patients with AD). Recent work has also highlighted the importance of a healthy and detoxified innate response by consuming diet precursors and enhancing responsiveness [171]. For instance, the application of radiation health, such as UV radiation from the Sun, can prepare an individual for further UV exposure [172]. Another example includes exposure to pro-oxidants such as $\mathrm{H}_{2} \mathrm{O}_{2}$, which can prepare the body for subsequent pro-oxidant exposure, which is similar to the formation of antibodies in vaccines. 
Table 1. Overview of the experimentally documented roles of various known natural antioxidant compounds in cases of Alzheimer's disease.

\begin{tabular}{|c|c|c|c|}
\hline Antioxidant & Mechanism & Experimental Model & Reference \\
\hline \multicolumn{4}{|l|}{ Vitamins } \\
\hline$\alpha$-Tocopherol & $\begin{array}{l}\text { Reduces } A \beta \text { and lipid peroxidation; delays development of tau } \\
\text { pathology; reduction in learning deficits and motor weakness }\end{array}$ & Tg2576 mice & {$[156,157,167-170,173]$} \\
\hline Ascorbic acid & Reduces $A \beta$ oligomers, tau phosphorylation, and oxidative stress & $\begin{array}{l}\text { hAPP-J20 mice } \\
\text { APPswe/ }\end{array}$ & [174] \\
\hline Retinol & $\begin{array}{c}\text { Reduces MDA levels; upregulates SOD activity; reduces A } \beta \\
\text { pathology }\end{array}$ & $\begin{array}{c}\text { PS1M146V / } \\
\text { tauP301L }(3 \times \mathrm{Tg}) \text { mice; in vitro enzymatic assay } \\
\text { and in silico modeling }\end{array}$ & [175] \\
\hline \multicolumn{4}{|l|}{ Naturally present } \\
\hline CoQ10 & $\begin{array}{l}\text { Reduces MDA levels; upregulates SOD activity; reduces A } \beta \\
\text { pathology }\end{array}$ & Tg19959 mice; APP/PS1 Tg mice & {$[176,177]$} \\
\hline \multicolumn{4}{|l|}{ Synthetic } \\
\hline Mito Q & $\begin{array}{l}\text { Prevents cognitive decline, oxidative stress, } \mathrm{A} \beta \text { accumulation, } \\
\text { synaptic loss, and caspase activation }\end{array}$ & $3 \times$ Tg mice & [178] \\
\hline \multicolumn{4}{|l|}{ Plant-based } \\
\hline$\beta$-Carotene & Improves cognitive impairment and oxidative stress & Streptozotocin-induced AD mice model & [180] \\
\hline Curcumin & $\begin{array}{l}\text { Inhibits } A \beta \text { fibrillization and oligomerization; clearance of } A \beta \text { by } \\
\text { macrophages; reduces } A \beta 40 \text { and } 42 \text { and } A \beta \text {-derived diffusible } \\
\text { ligands; increases } A \beta \text {-degrading enzymes; promotes destabilization }\end{array}$ & $\begin{array}{l}\text { Tg2576 mice; APPSw mice; APPswe/PS1dE9 } \\
\text { mice; in vitro enzymatic assay }\end{array}$ & {$[160-163,181]$} \\
\hline Ferulic acid & Inhibits the fibrillization and/or oligomerization of $A \beta$ & \multirow{3}{*}{$\begin{array}{c}\text { In vitro enzymatic assay } \\
\text { Molecular docking analysis; Tg2576 mice; PC12 } \\
\text { neuroblastoma } \\
\text { Tg2576 mice }\end{array}$} & {$[167,168]$} \\
\hline Rosmarinic acid & Inhibits the fibrillization and/or oligomerization of $A \beta$ & & {$[168-170]$} \\
\hline Nordihydroguaiaretic acid (NDGA) & Inhibits the fibrillization and/or oligomerization of $A \beta$ & & [168] \\
\hline \multicolumn{4}{|l|}{ Mimetic } \\
\hline ApoE mimetic peptide Ac-hE18A-NH2 & $\begin{array}{l}\text { Reduces oxidative stress and ApoE secretion; inhibits } A \beta \text { plaque } \\
\text { deposition }\end{array}$ & $\begin{array}{l}\mathrm{APP} / \mathrm{PS} 1 \Delta \mathrm{E} 9 \text { mice and U251 human astrocyte } \\
\text { cells }\end{array}$ & [182] \\
\hline Catalase mimetic & $\begin{array}{l}\text { Protects against oxidative stress, DNA, and protein oxidation; } \\
\text { reduces } \mathrm{A} \beta \text { and tau phosphorylation }\end{array}$ & $3 \times \mathrm{Tg}-\mathrm{AD}$ mice & [183] \\
\hline
\end{tabular}


Table 1. Cont

\section{Antioxidant}

Drug

Melatonin

N-Acetyl-L-cysteine
Mechanism

Experimental Model

Reference

Inhibits time-dependent elevation of $A \beta \cdot$ reduces abnorma

oxidation and nitration of proteins; increases survival; alleviates

learning and memory deficits; decreases choline acetyltransferase

activity and increases acetyltransferase activity; increases

Tg2576 mice; APP 695 Tg mouse model; APP/PS1

mice; APPswePS1dE9 mice

$[166,184-187]$

mitochondrial function

Reduces lipid peroxidation, oxidative stress, and glutathione peroxidase activity 


\title{
6. Conclusions
}

ROS are the byproducts of normal cell metabolism and are therefore unavoidable. However, an imbalance between pro-oxidative and antioxidative cellular mechanisms leads to a vicious cycle since OS reciprocally aggravates ROS production, which results in the oxidation of lipids, proteins, and NA in neurons. This oxidation is a frequently encountered pathological marker in the case of $\mathrm{AD}$. It contributes to the disease's progression by increasing $\mathrm{A} \beta$ deposition, hyperphosphorylation of tau, and synaptic and neuronal loss. Altogether, the relationship between $\mathrm{OS}$ and $\mathrm{AD}$ suggests that $\mathrm{OS}$ is an essential part of the pathological process and that antioxidants may be helpful in treating AD. However, AD demands a precisely targeted treatment. Furthermore, non-antioxidant, targeted protection against OS, including transition metal chelators, compounds that modify the oligomeric structure, and inhibitors of enzymatic ROS production (such an NADPH oxidase), may potentially exert a strong therapeutic effect against AD. Additionally, consumption of precursors in the diet and mild exposure to pro-oxidants can benefit future exposure to the same stressor. All of these approaches are currently being rapidly developed.

Author Contributions: C.S. and S.R.K. designed and co-wrote the manuscript. C.S. provided the references for the manuscript. C.S. and S.R.K. prepared all figures and tables. S.R.K. supervised the writing of the manuscript. All authors have read and agreed to the published version of the manuscript.

Funding: This research was supported and funded by the grant received from the National Research Foundation of Korea (NRF-2020R1A2C2007954). The APC was funded by the same funding agency.

Conflicts of Interest: The authors declare that there is no conflict of interest.

\begin{abstract}
Abbreviations
ROS: Reactive oxygen species; AD: Alzheimer's disease; OS: Oxidative stress; TFs: Transcription factors; ETC: Electron transport chain; OXPHOS: Oxidative phosphorylation; Nrf2: NF-E2-related factor 2; Keap1: Kelch-like ECH-associated protein 1; Maf: Musculoaponeurotic fibrosarcoma; AREs: Antioxidant response elements; Nqo1: NAD(P)H quinone oxidoreductae 1; Hmox1: Heme oxygenase 1; GSTs: Glutathione S transferases; APP: Amyloid beta precursor protein; A $\beta$ : Amyloid beta; HNE: hydroxynonenal; PUFAs: Polyunsaturated fatty acids; NA: Nucleic acids; 8-OHdG: 8-hydroxy-2deoxyguanosine; MDA: Malondialdehyde; 4-HNE: 4-hydroxy-2-nonenal; AGEs: Advanced glycation end products; RAGEs: Receptors for AGEs; WT: Wild-type; HSP: Heat shock proteins; TM: Transition metals; ER: Endoplasmic reticulum; GA: Golgi apparatus; BACE1: $\beta$-site APP cleaving enzyme 1; PM: Plasma membrane; AChRs: $\alpha 7$-acetylcholine receptors; NMDARs: N-methyl-D-aspartate receptors; GSK-3 $\beta$ : Glycogen synthase kinase 3 beta; CREB: cAMP response element-binding protein; MEF2: Myocyte enhancer factor 2; AMPARs: $\alpha$-Amino-3-hydroxy-5-methyl-4-isoxazolepropionic acid receptors; NO: Nitric oxide; TCA: Tricarboxylic acid; ApoE: Apolipoprotein E; NFTs: Neurofibrillary tangles; NADH: Nicotinamide adenine dinucleotide; ATP: Adenosine triphosphate; VDAC1: Voltage dependent anion channel 1; $\mathrm{mt} \triangle \Psi$ : Mitochondrial membrane potential; NADPH: Nicotinamide adenine dinucleotide phosphate; MAP: Microtubule-associated protein; NDGA: Nordihydroguaiaretic acid.
\end{abstract}

\section{References}

1. Finkel, T. Signal transduction by reactive oxygen species. J. Cell Biol. 2011, 194, 7-15. [CrossRef]

2. Dröge, W. Free radicals in the physiological control of cell function. Physiol. Rev. 2002, 82, 47-95. [CrossRef]

3. Wood, Z.A.; Poole, L.B.; Karplus, P.A. Peroxiredoxin evolution and the regulation of hydrogen peroxide signaling. Science 2003, 300, 650-653. [CrossRef]

4. Kiley, P.J.; Storz, G. Exploiting Thiol Modifications. PLoS Biol. 2004, 2, e400. [CrossRef]

5. Cui, H.; Kong, Y.; Zhang, H. Oxidative Stress, Mitochondrial Dysfunction, and Aging. J. Signal Transduct. 2012, 2012, 1-13. [CrossRef]

6. Brand, M.D. The sites and topology of mitochondrial superoxide production. Exp. Gerontol. 2010, 45, 466-472. [CrossRef] [PubMed] 
7. Quinlan, C.L.; Goncalves, R.L.S.; Hey-Mogensen, M.; Yadava, N.; Bunik, V.I.; Brand, M.D. The 2-oxoacid dehydrogenase complexes in mitochondria can produce superoxide/hydrogen peroxide at much higher rates than complex I. J. Biol. Chem. 2014, 289, 8312-8325. [CrossRef] [PubMed]

8. Sykiotis, G.P.; Bohmann, D. Stress-activated cap'n'collar transcription factors in aging and human disease. Sci. Signal. 2010, 3, re3. [CrossRef]

9. Holland, R.; Fishbein, J.C. Chemistry of the cysteine sensors in kelch-like ECH-associated protein. Antioxid. Redox Signal. 2010, 13, 1749-1761. [CrossRef] [PubMed]

10. Niforou, K.; Cheimonidou, C.; Trougakos, I.P. Molecular chaperones and proteostasis regulation during redox imbalance. Redox Biol. 2014, 2, 323-332. [CrossRef] [PubMed]

11. Giudice, A.; Arra, C.; Turco, M.C. Review of molecular mechanisms involved in the activation of the Nrf2-ARE signaling pathway by chemopreventive agents. Methods Mol. Biol. 2010, 647, 37-74.

12. Copple, I.M.; Goldring, C.E.; Kitteringham, N.R.; Park, B.K. The Keap1-Nrf2 cellular defense pathway: Mechanisms of regulation and role in protection against drug-induced toxicity. Handb. Exp. Pharmacol. 2010, 196, 233-266.

13. Hensen, S.M.M.; Heldens, L.; van Enckevort, C.M.W.; Van Genesen, S.T.; Pruijn, G.J.M.; Lubsen, N.H. Activation of the antioxidant response in methionine deprived human cells results in an HSF1-independent increase in HSPA1A mRNA levels. Biochimie 2013, 95, 1245-1251. [CrossRef] [PubMed]

14. Tsakiri, E.N.; Iliaki, K.K.; Höhn, A.; Grimm, S.; Papassideri, I.S.; Grune, T.; Trougakos, I.P. Diet-derived advanced glycation end products or lipofuscin disrupts proteostasis and reduces life span in Drosophila melanogaster. Free Radic. Biol. Med. 2013, 65, 1155-1163. [CrossRef]

15. Tsakiri, E.N.; Sykiotis, G.P.; Papassideri, I.S.; Terpos, E.; Dimopoulos, M.A.; Gorgoulis, V.G.; Bohmann, D.; Trougakos, I.P. Proteasome dysfunction in Drosophila signals to an Nrf2-dependent regulatory circuit aiming to restore proteostasis and prevent premature aging. Aging Cell 2013, 12, 802-813. [CrossRef] [PubMed]

16. Martindale, J.L.; Holbrook, N.J. Cellular response to oxidative stress: Signaling for suicide and survival. J. Cell. Physiol. 2002, 192, 1-15. [CrossRef] [PubMed]

17. Butterfield, D.A.; Drake, J.; Pocernich, C.; Castegna, A. Evidence of oxidative damage in Alzheimer's disease brain: Central role for amyloid $\beta$-peptide. Trends Mol. Med. 2001, 7, 548-554. [CrossRef]

18. Tabner, B.J.; El-Agnaf, O.M.A.; German, M.J.; Fullwood, N.J.; Allsop, D. Protein aggregation, metals and oxidative stress in neurodegenerative diseases. Biochem. Soc. Trans. 2005, 33, 1082-1086. [CrossRef]

19. Pérez, V.I.; Buffenstein, R.; Masamsetti, V.; Leonard, S.; Salmon, A.B.; Mele, J.; Andziak, B.; Yang, T.; Edrey, Y.; Friguet, B.; et al. Protein stability and resistance to oxidative stress are determinants of longevity in the longest-living rodent, the naked mole-rat. Proc. Natl. Acad. Sci. USA 2009, 106, 3059-3064. [CrossRef]

20. Nedić, O.; Rattan, S.I.S.; Grune, T.; Trougakos, I.P. Molecular effects of advanced glycation end products on cell signalling pathways, ageing and pathophysiology. Free Radic. Res. 2013, 47, 28-38. [CrossRef]

21. Tamagno, E.; Bardini, P.; Obbili, A.; Vitali, A.; Borghi, R.; Zaccheo, D.; Pronzato, M.A.; Danni, O.; Smith, M.A.; Perry, G.; et al. Oxidative stress increases expression and activity of BACE in NT2 neurons. Neurobiol. Dis. 2002, 10, 279-288. [CrossRef] [PubMed]

22. Tamagno, E.; Parola, M.; Bardini, P.; Piccini, A.; Borghi, R.; Guglielmotto, M.; Santoro, G.; Davit, A.; Danni, O.; Smith, M.A.; et al. $\beta$-site APP cleaving enzyme up-regulation induced by 4-hydroxynonenal is mediated by stress-activated protein kinases pathways. J. Neurochem. 2005, 92, 628-636. [CrossRef] [PubMed]

23. McLaurin, J.; Lai, A.Y. Mechanisms of amyloid-beta peptide uptake by neurons: The role of lipid rafts and lipid raft-associated proteins. Int. J. Alzheimers Dis. 2011, 2011, 548380. [CrossRef]

24. Reddy, P.H.; Beal, M.F. Amyloid beta, mitochondrial dysfunction and synaptic damage: Implications for cognitive decline in aging and Alzheimer's disease. Trends Mol. Med. 2008, 14, 45-53. [CrossRef] [PubMed]

25. Nunomura, A.; Castellani, R.J.; Zhu, X.; Moreira, P.I.; Perry, G.; Smith, M.A. Involvement of oxidative stress in Alzheimer disease. J. Neuropathol. Exp. Neurol. 2006, 65, 631-641. [CrossRef]

26. Jeandel, C.; Nicolas, M.B.; Dubois, F.; Nabet-Belleville, F.; Penin, F.; Cuny, G. Lipid peroxidation and free radical scavengers in Alzheimer's disease. Gerontology 1989, 35, 275-282. [CrossRef] [PubMed]

27. Subbarao, K.V.; Richardson, J.S.; Ang, L.C. Autopsy Samples of Alzheimer's Cortex Show Increased Peroxidation In Vitro. J. Neurochem. 1990, 55, 342-345. [CrossRef]

28. Mecocci, P.; MacGarvey, U.; Beal, M.F. Oxidative damage to mitochondrial DNA is increased in Alzheimer's disease. Ann. Neurol. 1994, 36, 747-751. [CrossRef]

29. Gabbita, S.P.; Lovell, M.A.; Markesbery, W.R. Increased nuclear DNA oxidation in the brain in Alzheimer' s disease. J. Neurochem. 1998, 71, 2034-2040. [CrossRef]

30. Nunomura, A.; Perry, G.; Pappolla, M.A.; Wade, R.; Hirai, K.; Chiba, S.; Smith, M.A. RNA oxidation is a prominent feature of vulnerable neurons in Alzheimer's disease. J. Neurosci. 1999, 19, 1959-1964. [CrossRef]

31. Evans, M.D.; Dizdaroglu, M.; Cooke, M.S. Oxidative DNA damage and disease: Induction, repair and significance. Mutat. Res. Rev. Mutat. Res. 2004, 567, 1-61. [CrossRef] [PubMed]

32. Höhn, A.; Tramutola, A.; Cascella, R. Proteostasis Failure in Neurodegenerative Diseases: Focus on Oxidative Stress. Oxid. Med. Cell. Longev. 2020, 2020, 5497046. [CrossRef] 
33. Praticò, D. Oxidative stress hypothesis in Alzheimer's disease: A reappraisal. Trends Pharmacol. Sci. 2008, 29, 609-615. [CrossRef] [PubMed]

34. Schmidt, A.M.; Du Yan, S.; Yan, S.F.; Stern, D.M. The Biology of the Receptor for Advanced Glycation end Products and Its Ligands. Biochim. Biophys. Acta 2000, 1498, 99-111. [CrossRef]

35. Gkogkolou, P.; Böhm, M. Advanced glycation end products: Keyplayers in skin aging? Dermatoendocrinology 2012, 4, 259. [CrossRef]

36. Maillard, L.C. Action of amino acids on sugars. Formation of melanoidins in a methodical way. Compte-Rendu L'academie Sci. 1912, 154, 66-68.

37. Smith, M.A.; Taneda, S.; Richey, P.L.; Miyata, S.; Yan, S.D.; Stern, D.; Sayre, L.M.; Monnier, V.M.; Perry, G. Advanced Maillard reaction end products are associated with Alzheimer disease pathology. Proc. Natl. Acad. Sci. USA 1994, 91, 5710-5714. [CrossRef]

38. Nunomura, A.; Perry, G.; Aliev, G.; Hirai, K.; Takeda, A.; Balraj, E.K.; Jones, P.K.; Ghanbari, H.; Wataya, T.; Shimohama, S.; et al. Oxidative damage is the earliest event in Alzheimer disease. J. Neuropathol. Exp. Neurol. 2001, 60, 759-767. [CrossRef] [PubMed]

39. Ghanbari, H.A.; Ghanbari, K.; Harris, P.L.R.; Jones, P.K.; Kubat, Z.; Castellani, R.J.; Wolozin, B.L.; Smith, M.A.; Perry, G. Oxidative damage in cultured human olfactory neurons from Alzheimer's disease patients. Aging Cell 2004, 3, 41-44. [CrossRef]

40. Migliore, L.; Fontana, I.; Trippi, F.; Colognato, R.; Coppedè, F.; Tognoni, G.; Nucciarone, B.; Siciliano, G. Oxidative DNA damage in peripheral leukocytes of mild cognitive impairment and AD patients. Neurobiol. Aging 2005, 26, 567-573. [CrossRef]

41. Moreira, P.I.; Harris, P.L.R.; Zhu, X.; Santos, M.S.; Oliveira, C.R.; Smith, M.A.; Perry, G. Lipoic acid and N-acetyl cysteine decrease mitochondrial-related oxidative stress in Alzheimer disease patient fibroblasts. J. Alzheimer Dis. 2007, 12, 195-206. [CrossRef]

42. O'Brien, R.J.; Wong, P.C. Amyloid precursor protein processing and Alzheimer's disease. Annu. Rev. Neurosci. 2011, 34, 185-204. [CrossRef]

43. Takalo, M.; Salminen, A.; Soininen, H.; Hiltunen, M.; Haapasalo, A. Protein aggregation and degradation mechanisms in neurodegenerative diseases. Am. J. Neurodegener. Dis. 2013, 2, 1-14. [PubMed]

44. Ciechanover, A.; Kwon, Y.T. Degradation of misfolded proteins in neurodegenerative diseases: Therapeutic targets and strategies. Exp. Mol. Med. 2015, 47, e147. [CrossRef]

45. Morimoto, R.I. Proteotoxic stress and inducible chaperone networks in neurodegenerative disease and aging. Genes Dev. 2008, 22, 1427-1438. [CrossRef]

46. Sen, C.K.; Packer, L. Antioxidant and redox regulation of gene transcription. FASEB J. 1996, 10, 709-720. [CrossRef]

47. Aiken, C.T.; Kaake, R.M.; Wang, X.; Huang, L. Oxidative Stress-Mediated Regulation of Proteasome Complexes. Mol. Cell. Proteom. 2011, 10, R110.006924. [CrossRef]

48. Pajares, M.; Jiménez-Moreno, N.; Dias, I.H.K.; Debelec, B.; Vucetic, M.; Fladmark, K.E.; Basaga, H.; Ribaric, S.; Milisav, I.; Cuadrado, A. Redox control of protein degradation. Redox Biol. 2015, 6, 409-420. [CrossRef] [PubMed]

49. Devi, L.; Prabhu, B.M.; Galati, D.F.; Avadhani, N.G.; Anandatheerthavarada, H.K. Accumulation of amyloid precursor protein in the mitochondrial import channels of human Alzheimer's disease brain is associated with mitochondrial dysfunction. J. Neurosci. 2006, 26, 9057-9068. [CrossRef] [PubMed]

50. Wang, X.; Su, B.; Lee, H.G.; Li, X.; Perry, G.; Smith, M.A.; Zhu, X. Impaired balance of mitochondrial fission and fusion in Alzheimer's disease. J. Neurosci. 2009, 29, 9090-9103. [CrossRef] [PubMed]

51. Haass, C.; Kaether, C.; Thinakaran, G.; Sisodia, S. Trafficking and proteolytic processing of APP. Cold Spring Harb. Perspect. Med. 2012, 2, a006270. [CrossRef]

52. Rajendran, L.; Annaert, W. Membrane Trafficking Pathways in Alzheimer's Disease. Traffic 2012, 13, 759-770. [CrossRef] [PubMed]

53. Kiyota, T.; Zhang, G.; Morrison, C.M.; Bosch, M.E.; Weir, R.A.; Lu, Y.; Dong, W.; Gendelman, H.E. AAV2/1 CD74 Gene Transfer Reduces $\beta$-amyloidosis and Improves Learning and Memory in a Mouse Model of Alzheimer's Disease. Mol. Ther. 2015, 23, 1712-1721. [CrossRef]

54. Pimplikar, S.W.; Nixon, R.A.; Robakis, N.K.; Shen, J.; Tsai, L.H. Amyloid-independent mechanisms in Alzheimer's disease pathogenesis. J. Neurosci. 2010, 30, 14946-14954. [CrossRef] [PubMed]

55. Rajendran, L.; Honsho, M.; Zahn, T.R.; Keller, P.; Geiger, K.D.; Verkade, P.; Simons, K. Alzheimer's disease $\beta$-amyloid peptides are released in association with exosomes. Proc. Natl. Acad. Sci. USA 2006, 103, 11172-11177. [CrossRef] [PubMed]

56. Pacheco-Quinto, J.; Eckman, E.A. Endothelin-converting enzymes degrade intracellular $\beta$-amyloid produced within the endosomal/lysosomal pathway and autophagosomes. J. Biol. Chem. 2013, 288, 5606-5615. [CrossRef] [PubMed]

57. Jiang, S.; Li, Y.; Zhang, X.; Bu, G.; Xu, H.; Zhang, Y.W. Trafficking regulation of proteins in Alzheimer's disease. Mol. Neurodegener. 2014, 9, 1-13. [CrossRef] [PubMed]

58. Chen, G.F.; Xu, T.H.; Yan, Y.; Zhou, Y.R.; Jiang, Y.; Melcher, K.; Xu, H.E. Amyloid beta: Structure, biology and structure-based therapeutic development. Acta Pharmacol. Sin. 2017, 38, 1205-1235. [CrossRef] [PubMed]

59. Mattson, M.P. Pathways towards and away from Alzheimer's disease. Nature 2004, 430, 631-639. [CrossRef]

60. Kolaj, I.; Imindu Liyanage, S.; Weaver, D.F. Phenylpropanoids and Alzheimer's disease: A potential therapeutic platform. Neurochem. Int. 2018, 120, 99-111. [CrossRef]

61. Armstrong, R.A. The pathogenesis of Alzheimer's disease: A reevaluation of the "amyloid cascade hypothesis". Int. J. Alzheimers. Dis. 2011, 2011, 630865. [CrossRef] 
62. Aksenov, M.Y.; Aksenova, M.V.; Harris, M.E.; Hensley, K.; Butterfield, D.A.; Carney, J.M. Enhancement of $\beta$-Amyloid Peptide

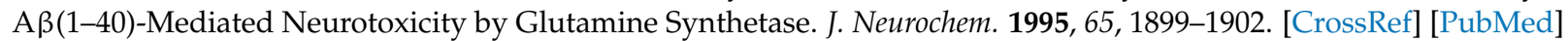

63. Hensley, K.; Carney, J.M.; Mattson, M.P.; Aksenova, M.; Harris, M.; Wu, J.F.; Floyd, R.A.; Butterfield, D.A. A model for $\beta$-amyloid aggregation and neurotoxicity based on free radical generation by the peptide: Relevance to Alzheimer disease. Proc. Natl. Acad. Sci. USA 1994, 91, 3270-3274. [CrossRef]

64. Casley, C.S.; Canevari, L.; Land, J.M.; Clark, J.B.; Sharpe, M.A. $\beta$-Amyloid inhibits integrated mitochondrial respiration and key enzyme activities. J. Neurochem. 2002, 80, 91-100. [CrossRef]

65. Hemachandra Reddy, P.; Flint Beal, M. Are mitochondria critical in the pathogenesis of Alzheimer's disease? Brain Res. Brain Res. Rev. 2005, 49, 618-632. [CrossRef]

66. Mhatre, M.; Floyd, R.A.; Hensley, K. Oxidative stress and neuroinflammation in Alzheimer's disease and amyotrophic lateral sclerosis: Common links and potential therapeutic targets. J. Alzheimers Dis. 2004, 6, 147-157. [CrossRef]

67. Kim, H.S.; Lee, J.H.; Lee, J.P.; Kim, E.M.; Chang, K.A.; Park, C.H.; Jeong, S.J.; Wittendorp, M.C.; Seo, J.H.; Choi, S.H.; et al. Amyloid $\beta$ peptide induces cytochrome c release from isolated mitochondria. Neuroreport 2002, 13, 1989-1993. [CrossRef] [PubMed]

68. Markesbery, W.R.; Lovell, M.A. Four-hydroxynonenal, a product of lipid peroxidation, is increased in the brain in Alzheimer's disease. Neurobiol. Aging 1998, 19, 33-36. [CrossRef]

69. Torres, L.L.; Quaglio, N.B.; De Souza, G.T.; Garcia, R.T.; Dati, L.M.M.; Moreira, W.L.; De Melo Loureiro, A.P.; De Souza-Talarico, J.N.; Smid, J.; Porto, C.S.; et al. Peripheral oxidative stress biomarkers in mild cognitive impairment and Alzheimer's disease. J. Alzheimer Dis. 2011, 26, 59-68. [CrossRef] [PubMed]

70. Williams, T.I.; Lynn, B.C.; Markesbery, W.R.; Lovell, M.A. Increased levels of 4-hydroxynonenal and acrolein, neurotoxic markers of lipid peroxidation, in the brain in Mild Cognitive Impairment and early Alzheimer's disease. Neurobiol. Aging 2006, 27, 1094-1099. [CrossRef] [PubMed]

71. Praticò, D.; Uryu, K.; Leight, S.; Trojanoswki, J.Q.; Lee, V.M.Y. Increased lipid peroxidation precedes amyloid plaque formation in an animal model of alzheimer amyloidosis. J. Neurosci. 2001, 21, 4183-4187. [CrossRef] [PubMed]

72. Gwon, A.R.; Park, J.S.; Arumugam, T.V.; Kwon, Y.K.; Chan, S.L.; Kim, S.H.; Baik, S.H.; Yang, S.; Yun, Y.K.; Choi, Y.; et al. Oxidative lipid modification of nicastrin enhances amyloidogenic $\gamma$-secretase activity in Alzheimer's disease. Aging Cell 2012, 11, 559-568. [CrossRef] [PubMed]

73. Huang, X.; Atwood, C.S.; Hartshorn, M.A.; Multhaup, G.; Goldstein, L.E.; Scarpa, R.C.; Cuajungco, M.P.; Gray, D.N.; Lim, J.; Moir, R.D.; et al. The A $\beta$ peptide of Alzheimer's disease directly produces hydrogen peroxide through metal ion reduction. Biochemistry 1999, 38, 7609-7616. [CrossRef] [PubMed]

74. Opazo, C.; Huang, X.; Cherny, R.A.; Moir, R.D.; Roher, A.E.; White, A.R.; Cappai, R.; Masters, C.L.; Tanzi, R.E.; Inestrosa, N.C.; et al. Metalloenzyme-like activity of Alzheimer's disease $\beta$-amyloid: Cu-dependent catalytic conversion of dopamine, cholesterol, and biological reducing agents to neurotoxic $\mathrm{H}_{2} \mathrm{O}$. J. Biol. Chem. 2002, 277, 40302-40308. [CrossRef]

75. Nelson, T.J.; Alkon, D.L. Oxidation of cholesterol by amyloid precursor protein and $\beta$-amyloid peptide. J. Biol. Chem. 2005, 280, 7377-7387. [CrossRef]

76. Ortwerth, B.J.; Olesen, P.R. Ascorbic acid-induced crosslinking of lens proteins: Evidence supporting a Maillard reaction. Biochim. Biophys. Acta BBA Protein Struct. Mol. 1988, 956, 10-22. [CrossRef]

77. Prabhakaram, M.; Ortwerth, B.J. Determination of glycation crosslinking by the sugar-dependent incorporation of $\left[{ }^{14} \mathrm{C}\right]$ lysine into protein. Anal. Biochem. 1994, 216, 305-312. [CrossRef] [PubMed]

78. Münch, G.; Cunningham, A.M.; Riederer, P.; Braak, E. Advanced glycation endproducts are associated with Hirano bodies in Alzheimer's disease. Brain Res. 1998, 796, 307-310. [CrossRef]

79. Li, Y.M.; Dickson, D.W. Enhanced binding of advanced glycation endproducts (AGE) by the ApoE4 isoform links the mechanism of plaque deposition in Alzheimer's disease. Neurosci. Lett. 1997, 226, 155-158. [CrossRef]

80. Kim, D.E.; Priefer, R. Therapeutic Potential of Direct Clearance of the Amyloid- $\beta$ in Alzheimer's Disease. Brain Sci. 2020, 10, 93. [CrossRef]

81. Jianyi, M.; Ann, Y.; Brewer, B.H., Jr.; Saumya, D.; Huntington, P. Amyloid-associated proteins alpha 1-antichymotrypsin and apolipoprotein E promote assembly of Alzheimer beta-protein into filaments. Nature 1994, 372, 92-94. [CrossRef]

82. Kloske, C.M.; Wilcock, D.M. The Important Interface between Apolipoprotein E and Neuroinflammation in Alzheimer's Disease. Front. Immunol. 2020, 11, 754. [CrossRef] [PubMed]

83. Chen, J.; Mooldijk, S.S.; Licher, S.; Waqas, K.; Ikram, M.K.; Uitterlinden, A.G.; Zillikens, M.C.; Ikram, M.A. Assessment of Advanced Glycation End Products and Receptors and the Risk of Dementia. JAMA Netw. Open 2021, 4, e2033012. [CrossRef] [PubMed]

84. Deibel, M.A.; Ehmann, W.D.; Markesbery, W.R. Copper, iron, and zinc imbalances in severely degenerated brain regions in Alzheimer's disease: Possible relation to oxidative stress. J. Neurol. Sci. 1996, 143, 137-142. [CrossRef]

85. Greenough, M.A.; Camakaris, J.; Bush, A.I. Metal dyshomeostasis and oxidative stress in Alzheimer's disease. Neurochem. Int. 2013, 62, 540-555. [CrossRef] [PubMed]

86. Liu, Y.; Nguyen, M.; Robert, A.; Meunier, B. Metal Ions in Alzheimer's Disease: A Key Role or Not? Acc. Chem. Res. 2019, 52, 2026-2035. [CrossRef] [PubMed]

87. Jomova, K.; Vondrakova, D.; Lawson, M.; Valko, M. Metals, oxidative stress and neurodegenerative disorders. Mol. Cell. Biochem. 2010, 345, 91-104. [CrossRef] 
88. Eskici, G.; Axelsen, P.H. Copper and oxidative stress in the pathogenesis of Alzheimer's disease. Biochemistry 2012, 51, 6289-6311. [CrossRef]

89. Curtain, C.C.; Ali, F.; Volitakis, I.; Cherny, R.A.; Norton, R.S.; Beyreuther, K.; Barrow, C.J.; Masters, C.L.; Bush, A.I.; Barnham, K.J. Alzheimer's Disease Amyloid- $\beta$ Binds Copper and Zinc to Generate an Allosterically Ordered Membrane-penetrating Structure Containing Superoxide Dismutase-like Subunits. J. Biol. Chem. 2001, 276, 20466-20473. [CrossRef]

90. Scheiber, I.F.; Dringen, R. Astrocyte functions in the copper homeostasis of the brain. Neurochem. Int. 2013, 62, 556-565. [CrossRef] [PubMed]

91. Wan, L.; Nie, G.; Zhang, J.; Luo, Y.; Zhang, P.; Zhang, Z.; Zhao, B. $\beta$-Amyloid peptide increases levels of iron content and oxidative stress in human cell and Caenorhabditis elegans models of Alzheimer disease. Free Radic. Biol. Med. 2011, 50, 122-129. [CrossRef]

92. Honda, K.; Casadesus, G.; Petersen, R.B.; Perry, G.; Smith, M.A. Oxidative stress and redox-active iron in Alzheimer's disease. Ann. N. Y. Acad. Sci. 2004, 1012, 179-182. [CrossRef]

93. Sensi, S.L.; Rapposelli, I.G.; Frazzini, V.; Mascetra, N. Altered oxidant-mediated intraneuronal zinc mobilization in a triple transgenic mouse model of Alzheimer's disease. Exp. Gerontol. 2008, 43, 488-492. [CrossRef]

94. Lee, V.M.Y.; Goedert, M.; Trojanowski, J.Q. Neurodegenerative tauopathies. Annu. Rev. Neurosci. 2001, 24, 1121-1159. [CrossRef]

95. Drewes, G.; Ebneth, A.; Mandelkow, E.M. MAPs, MARKs and microtubule dynamics. Trends Biochem. Sci. 1998, 23, 307-311. [CrossRef]

96. Lewis, J.; Dickson, D.W.; Lin, W.L.; Chisholm, L.; Corral, A.; Jones, G.; Yen, S.H.; Sahara, N.; Skipper, L.; Yager, D.; et al. Enhanced neurofibrillary degeneration in transgenic mice expressing mutant tau and APP. Science 2001, 293, 1487-1491. [CrossRef]

97. Deture, M.A.; Dickson, D.W. The neuropathological diagnosis of Alzheimer's disease. Mol. Neurodegener. 2019, 14, 1-18. [CrossRef]

98. Moloney, C.M.; Lowe, V.J.; Murray, M.E. Visualization of neurofibrillary tangle maturity in Alzheimer's disease: A clinicopathologic perspective for biomarker research. Alzheimer's Dement. 2021. [CrossRef]

99. Kundel, F.; Hong, L.; Falcon, B.; McEwan, W.A.; Michaels, T.C.T.; Meisl, G.; Esteras, N.; Abramov, A.Y.; Knowles, T.J.P.; Goedert, M.; et al. Measurement of Tau Filament Fragmentation Provides Insights into Prion-like Spreading. ACS Chem. Neurosci. 2018, 9 , 1276-1282. [CrossRef]

100. Martin, L.; Latypova, X.; Wilson, C.M.; Magnaudeix, A.; Perrin, M.L.; Terro, F. Tau protein phosphatases in Alzheimer's disease: The leading role of PP2A. Ageing Res. Rev. 2013, 12, 39-49. [CrossRef]

101. Götz, J.; Chen, F.; Van Dorpe, J.; Nitsch, R.M. Formation of neurofibrillary tangles in P301L tau transgenic mice induced by A 342 fibrils. Science 2001, 293, 1491-1495. [CrossRef]

102. Uddin, M.S.; Kabir, M.T. Oxidative Stress in Alzheimer's Disease: Molecular Hallmarks of Underlying Vulnerability. In Biological, Diagnostic and Therapeutic Advances in Alzheimer's Disease: Non-Pharmacological Therapies for Alzheimer's Disease; Springer: Singapore, 2019; p. 91, ISBN 9789811396366.

103. Stamer, K.; Vogel, R.; Thies, E.; Mandelkow, E.; Mandelkow, E.M. Tau blocks traffic of organelles, neurofilaments, and APP vesicles in neurons and enhances oxidative stress. J. Cell Biol. 2002, 156, 1051-1063. [CrossRef]

104. Petersen, J.D.; Kaech, S.; Banker, G. Selective microtubule-based transport of dendritic membrane proteins arises in concert with axon specification. J. Neurosci. 2014, 34, 4135-4147. [CrossRef] [PubMed]

105. Gendron, T.F. The role of tau in neurodegeneration. Mol. Neurodegener. 2009, 4, 13. [CrossRef]

106. Kandimalla, R.; Manczak, M.; Yin, X.; Wang, R.; Reddy, P.H. Hippocampal phosphorylated tau induced cognitive decline, dendritic spine loss and mitochondrial abnormalities in a mouse model of Alzheimer's disease. Hum. Mol. Genet. 2018, 27, 30-40. [CrossRef] [PubMed]

107. Melov, S.; Adlard, P.A.; Morten, K.; Johnson, F.; Golden, T.R.; Hinerfeld, D.; Schilling, B.; Mavros, C.; Masters, C.L.; Volitakis, I.; et al. Mitochondrial oxidative stress causes hyperphosphorylation of tau. PLoS ONE 2007, 2, 536. [CrossRef] [PubMed]

108. David, D.C.; Hauptmann, S.; Scherping, I.; Schuessel, K.; Keil, U.; Rizzu, P.; Ravid, R.; Dröse, S.; Brandt, U.; Müller, W.E.; et al. Proteomic and functional analyses reveal a mitochondrial dysfunction in P301L tau transgenic mice. J. Biol. Chem. 2005, 280, 23802-23814. [CrossRef]

109. Yoshiyama, Y.; Higuchi, M.; Zhang, B.; Huang, S.M.; Iwata, N.; Saido, T.C.C.; Maeda, J.; Suhara, T.; Trojanowski, J.Q.; Lee, V.M.Y. Synapse Loss and Microglial Activation Precede Tangles in a P301S Tauopathy Mouse Model. Neuron 2007, 53, 337-351. [CrossRef]

110. Dubey, M.; Chaudhury, P.; Kabiru, H.; Shea, T.B. Tau inhibits anterograde axonal transport and perturbs stability in growing axonal neurites in part by displacing kinesin cargo: Neurofilaments attenuate tau-mediated neurite instability. Cell Motil. Cytoskelet. 2008, 65, 89-99. [CrossRef]

111. DuBoff, B.; Götz, J.; Feany, M.B. Tau Promotes Neurodegeneration via DRP1 Mislocalization In Vivo. Neuron 2012, 75, 618-632. [CrossRef]

112. Manczak, M.; Reddy, P.H. Abnormal interaction of VDAC1 with amyloid beta and phosphorylated tau causes mitochondrial dysfunction in Alzheimer's disease. Hum. Mol. Genet. 2012, 21, 5131-5146. [CrossRef] [PubMed]

113. Eckert, A.; Nisbet, R.; Grimm, A.; Götz, J. March separate, strike together-Role of phosphorylated TAU in mitochondrial dysfunction in Alzheimer's disease. Biochim. Biophys. Acta Mol. Basis Dis. 2014, 1842, 1258-1266. [CrossRef] [PubMed]

114. Esteras, N.; Kundel, F.; Amodeo, G.F.; Pavlov, E.V.; Klenerman, D.; Abramov, A.Y. Insoluble tau aggregates induce neuronal death through modification of membrane ion conductance, activation of voltage-gated calcium channels and NADPH oxidase. FEBS $J$. 2021, 288, 127-141. [CrossRef] 
115. Gella, A.; Durany, N. Oxidative stress in Alzheimer disease. Cell Adhes. Migr. 2009, 3, 88-93. [CrossRef] [PubMed]

116. González, C.; Farías, G.; Maccioni, R.B. Glycation of tau to an Alzheimer's type protein interferes with its interaction with microtubules. Cell. Mol. Boil. 1998, 44, 1117-1127.

117. Ledesma, M.D.; Pérez, M.; Colaco, C.; Avila, J. Tau glycation is involved in aggregation of the protein but not in the formation of filaments. Cell. Mol. Biol. 1998, 44, 1111-1116.

118. O'Toole, P.W.; Jeffery, I.B. Gut microbiota and aging. Science 2015, 350, 1214-1215. [CrossRef]

119. Collins, S.M.; Bercik, P. The relationship between intestinal microbiota and the central nervous system in normal gastrointestinal function and disease. Gastroenterology 2009, 136, 2003-2014. [CrossRef]

120. Collins, S.M.; Surette, M.G.; Bercik, P. The interplay between the intestinal microbiota and the brain. Nat. Rev. Microbiol. 2012, 10, 735-742. [CrossRef]

121. Cryan, J.F.; O'Mahony, S.M. The microbiome-gut-brain axis: From bowel to behavior. Neurogastroenterol. Motil. 2011, 23, 187-192. [CrossRef]

122. Belkaid, Y.; Hand, T. Role of the Microbiota in Immunity and inflammation. Cell 2014, 157, 121. [CrossRef]

123. Hooper, L.V.; Littman, D.R.; Macpherson, A.J. Interactions between the microbiota and the immune system. Science 2012, 336, 1268. [CrossRef]

124. Bhattacharjee, S.; Lukiw, W.J. Alzheimer's disease and the microbiome. Front. Cell. Neurosci. 2013, 7, 153. [CrossRef]

125. Douglas-Escobar, M.; Elliott, E.; Neu, J. Effect of Intestinal Microbial Ecology on the Developing Brain. JAMA Pediatr. 2013, 167, 374-379. [CrossRef]

126. Kowalski, K.; Mulak, A. Brain-Gut-Microbiota Axis in Alzheimer's Disease. J. Neurogastroenterol. Motil. 2019, 25, 48. [CrossRef]

127. Cattaneo, A.; Cattane, N.; Galluzzi, S.; Provasi, S.; Lopizzo, N.; Festari, C.; Ferrari, C.; Guerra, U.P.; Paghera, B.; Muscio, C.; et al. Association of brain amyloidosis with pro-inflammatory gut bacterial taxa and peripheral inflammation markers in cognitively impaired elderly. Neurobiol. Aging 2017, 49, 60-68. [CrossRef]

128. Minter, M.R.; Zhang, C.; Leone, V.; Ringus, D.L.; Zhang, X.; Oyler-Castrillo, P.; Musch, M.W.; Liao, F.; Ward, J.F.; Holtzman, D.M.; et al. Antibiotic-induced perturbations in gut microbial diversity influences neuro-inflammation and amyloidosis in a murine model of Alzheimer's disease. Sci. Rep. 2016, 6, 30028. [CrossRef]

129. Harach, T.; Marungruang, N.; Duthilleul, N.; Cheatham, V.; Coy, K.D.M.; Frisoni, G.; Neher, J.J.; Fåk, F.; Jucker, M.; Lasser, T.; et al. Reduction of Abeta amyloid pathology in APPPS1 transgenic mice in the absence of gut microbiota. Sci. Rep. 2017, 7, 1-15. [CrossRef]

130. Reese, A.T.; Cho, E.H.; Klitzman, B.; Nichols, S.P.; A Wisniewski, N.; Villa, M.M.; Durand, H.K.; Jiang, S.; Midani, F.S.; Nimmagadda, S.N.; et al. Antibiotic-induced changes in the microbiota disrupt redox dynamics in the gut. eLife 2018, 7, e35987. [CrossRef]

131. Mercante, J.W.; Neish, A.S. Reactive Oxygen Production Induced by the Gut Microbiota: Pharmacotherapeutic Implications. Curr. Med. Chem. 2012, 19, 1519-1529. [CrossRef]

132. Bonaz, B.; Bazin, T.; Pellissier, S. The Vagus Nerve at the Interface of the Microbiota-Gut-Brain Axis. Front. Neurosci. 2018, 12, 49. [CrossRef]

133. Cobley, J.N.; Fiorello, M.L.; Bailey, D.M. 13 reasons why the brain is susceptible to oxidative stress. Redox Biol. 2018, 15, 490-503. [CrossRef]

134. Friedland, R.P.; Chapman, M.R. The role of microbial amyloid in neurodegeneration. PLoS Pathog. 2017, 13, e1006654. [CrossRef]

135. Chen, S.G.; Stribinskis, V.; Rane, M.J.; Demuth, D.R.; Gozal, E.; Roberts, A.M.; Jagadapillai, R.; Liu, R.; Choe, K.; Shivakumar, B.; et al. Exposure to the Functional Bacterial Amyloid Protein Curli Enhances Alpha-Synuclein Aggregation in Aged Fischer 344 Rats and Caenorhabditis elegans. Sci. Rep. 2016, 6, 34477. [CrossRef]

136. Kahn, M.S.; Kranjac, D.; Alonzo, C.A.; Haase, J.H.; Cedillos, R.O.; McLinden, K.A.; Boehm, G.W.; Chumley, M.J. Prolonged elevation in hippocampal $A \beta$ and cognitive deficits following repeated endotoxin exposure in the mouse. Behav. Brain Res. 2012, 229, 176-184. [CrossRef]

137. Lundmark, K.; Westermark, G.T.; Olsen, A.; Westermark, P. Protein fibrils in nature can enhance amyloid protein A amyloidosis in mice: Cross-seeding as a disease mechanism. Proc. Natl. Acad. Sci. USA 2005, 102, 6098-6102. [CrossRef] [PubMed]

138. Zhou, Y.; Smith, D.; Leong, B.J.; Brännström, K.; Almqvist, F.; Chapman, M.R. Promiscuous Cross-seeding between Bacterial Amyloids Promotes Interspecies Biofilms. J. Biol. Chem. 2012, 287, 35092. [CrossRef]

139. Mitew, S.; Kirkcaldie, M.T.; Dickson, T.; Vickers, J.C. Altered synapses and gliotransmission in Alzheimer's disease and AD model mice. Neurobiol. Aging 2013, 34, 2341-2351. [CrossRef]

140. Brenner, S.R. Blue-green algae or cyanobacteria in the intestinal micro-flora may produce neurotoxins such as Beta-NMethylamino-l-Alanine (BMAA) which may be related to development of amyotrophic lateral sclerosis, Alzheimer's disease and Parkinson-Dementia-Complex in humans and Equine Motor Neuron Disease in Horses. Med. Hypotheses 2013, 80, 103. [CrossRef]

141. Schwartz, K.; Boles, B.R. Microbial amyloids-Functions and interactions within the host. Curr. Opin. Microbiol. 2013, 16, 93-99. [CrossRef]

142. Hill, J.M.; Zhao, Y.; Clement, C.; Neumann, D.M.; Lukiw, W.J. HSV-1 infection of human brain cells induces miRNA-146a and Alzheimer-type inflammatory signaling. Neuroreport 2009, 20, 1500. [CrossRef] [PubMed]

143. Ball, M.J.; Lukiw, W.J.; Kammerman, E.M.; Hill, J.M. Intracerebral propagation of Alzheimer's disease: Strengthening evidence of a herpes simplex virus etiology. Alzheimers Dement. 2013, 9, 169-175. [CrossRef] 
144. Manuelidis, L. Infectious particles, stress, and induced prion amyloids: A unifying perspective. Virulence 2013, 4, $373-383$. [CrossRef]

145. Köhler, C.; Maes, M.; Slyepchenko, A.; Berk, M.; Solmi, M.; Lanctôt, K.; Carvalho, A. The Gut-Brain Axis, Including the Microbiome, Leaky Gut and Bacterial Translocation: Mechanisms and Pathophysiological Role in Alzheimer's Disease. Curr. Pharm. Des. 2016, 22, 6152-6166. [CrossRef]

146. Pistollato, F.; Sumalla Cano, S.; Elio, I.; Masias Vergara, M.; Giampieri, F.; Battino, M. Role of gut microbiota and nutrients in amyloid formation and pathogenesis of Alzheimer disease. Nutr. Rev. 2016, 74, 624-634. [CrossRef]

147. Li, C.-Q.; Zheng, Q.; Wang, Q.; Zeng, Q.-P. Biotic/Abiotic Stress-Driven Alzheimer's Disease. Front. Cell. Neurosci. 2016, 10, 269. [CrossRef]

148. Chen, C.; Ahn, E.H.; Kang, S.S.; Liu, X.; Alam, A.; Ye, K. Gut dysbiosis contributes to amyloid pathology, associated with $\mathrm{C} / \mathrm{EBP} \beta / \mathrm{AEP}$ signaling activation in Alzheimer's disease mouse model. Sci. Adv. 2020, 6, eaba0466. [CrossRef] [PubMed]

149. Luca, M.; Di Mauro, M.; Di Mauro, M.; Luca, A. Gut Microbiota in Alzheimer's Disease, Depression, and Type 2 Diabetes Mellitus: The Role of Oxidative Stress. Oxid. Med. Cell. Longev. 2019, 2019, 4730539. [CrossRef] [PubMed]

150. Akbari, E.; Asemi, Z.; Kakhaki, R.D.; Bahmani, F.; Kouchaki, E.; Tamtaji, O.R.; Hamidi, G.A.; Salami, M. Effect of Probiotic Supplementation on Cognitive Function and Metabolic Status in Alzheimer's Disease: A Randomized, Double-Blind and Controlled Trial. Front. Aging Neurosci. 2016, 8, 256. [CrossRef]

151. Noble, J.M.; Scarmeas, N.; Celenti, R.S.; Elkind, M.S.V.; Wright, C.B.; Schupf, N.; Papapanou, P.N. Serum IgG Antibody Levels to Periodontal Microbiota Are Associated with Incident Alzheimer Disease. PLoS ONE 2014, 9, e114959. [CrossRef]

152. Xin, Y.; Diling, C.; Jian, Y.; Ting, L.; Guoyan, H.; Hualun, L.; Xiaocui, T.; Guoxiao, L.; Ou, S.; Chaoqun, Z.; et al. Effects of Oligosaccharides from Morinda officinalis on Gut Microbiota and Metabolome of APP/PS1 Transgenic Mice. Front. Neurol. 2018, 9, 412. [CrossRef] [PubMed]

153. Brandscheid, C.; Schuck, F.; Reinhardt, S.; Schäfer, K.-H.; Pietrzik, C.U.; Grimm, M.; Hartmann, T.; Schwiertz, A.; Endres, K. Altered Gut Microbiome Composition and Tryptic Activity of the 5xFAD Alzheimer's Mouse Model. J. Alzheimers. Dis. 2017, 56, 775-788. [CrossRef]

154. Bonfili, L.; Cecarini, V.; Berardi, S.; Scarpona, S.; Suchodolski, J.S.; Nasuti, C.; Fiorini, D.; Boarelli, M.C.; Rossi, G.; Eleuteri, A.M Microbiota modulation counteracts Alzheimer's disease progression influencing neuronal proteolysis and gut hormones plasma levels. Sci. Rep. 2017, 7, 1-21. [CrossRef]

155. Du, X.T.; Wang, L.; Wang, Y.J.; Andreasen, M.; Zhan, D.W.; Feng, Y.; Li, M.; Zhao, M.; Otzen, D.; Xue, D.; et al. A $\beta 1-16$ can aggregate and induce the production of reactive oxygen species, nitric oxide, and inflammatory cytokines. J. Alzheimer Dis. 2011, 27, 401-413. [CrossRef]

156. Bhatti, A.B.; Usman, M.; Ali, F.; Satti, S.A. Vitamin supplementation as an adjuvant treatment for Alzheimer's disease. J. Clin. Diagn. Res. 2016, 10, OE07-OE11. [CrossRef]

157. Ono, K.; Yamada, M. Vitamin A and Alzheimer's disease. Geriatr. Gerontol. Int. 2012, 12, 180-188. [CrossRef]

158. Sung, S.; Yao, Y.; Uryu, K.; Yang, H.; Lee, V.M.Y.; Trojanowski, J.Q.; Praticò, D. Early vitamin E supplementation in young but not aged mice reduces Abeta levels and amyloid deposition in a transgenic model of Alzheimer's disease. FASEB J. 2004, 18, 323-325. [CrossRef]

159. Conte, V.; Uryu, K.; Fujimoto, S.; Yao, Y.; Rokach, J.; Longhi, L.; Trojanowski, J.Q.; Lee, V.M.Y.; McIntosh, T.K.; Praticò, D. Vitamin E reduces amyloidosis and improves cognitive function in Tg2576 mice following repetitive concussive brain injury. J. Neurochem. 2004, 90, 758-764. [CrossRef] [PubMed]

160. Lim, G.P.; Chu, T.; Yang, F.; Beech, W.; Frautschy, S.A.; Cole, G.M. The curry spice curcumin reduces oxidative damage and amyloid pathology in an Alzheimer transgenic mouse. J. Neurosci. 2001, 21, 8370-8377. [CrossRef]

161. Ono, K.; Hasegawa, K.; Naiki, H.; Yamada, M. Curcumin Has Potent Anti-Amyloidogenic Effects for Alzheimer's $\beta$-Amyloid Fibrils In Vitro. J. Neurosci. Res. 2004, 75, 742-750. [CrossRef] [PubMed]

162. Yang, F.; Lim, G.P.; Begum, A.N.; Ubeda, O.J.; Simmons, M.R.; Ambegaokar, S.S.; Chen, P.; Kayed, R.; Glabe, C.G.; Frautschy, S.A.; et al. Curcumin inhibits formation of amyloid $\beta$ oligomers and fibrils, binds plaques, and reduces amyloid in vivo. J. Biol. Chem. 2005, 280, 5892-5901. [CrossRef]

163. Zhang, L.; Fiala, M.; Cashman, J.; Sayre, J.; Espinosa, A.; Mahanian, M.; Zaghi, J.; Badmaev, V.; Graves, M.C.; Bernard, G.; et al. Curcuminoids enhance amyloid- $\beta$ uptake by macrophages of Alzheimer's disease patients. J. Alzheimer Dis. 2006, 10, 1-7. [CrossRef]

164. Balogun, E.; Hoque, M.; Gong, P.; Killeen, E.; Green, C.J.; Foresti, R.; Alam, J.; Motterlini, R. Curcumin activates the haem oxygenase-1 gene via regulation of Nrf2 and the antioxidant-responsive element. Biochem. J. 2003, 371, 887-895. [CrossRef] [PubMed]

165. Wruck, C.J.; Claussen, M.; Fuhrmann, G.; Römer, L.; Schulz, A.; Pufe, T.; Waetzig, V.; Peipp, M.; Herdegen, T.; Götz, M.E. Luteolin protects rat PC 12 and C6 cells against MPP+ induced toxicity via an ERK dependent Keapl-Nrf2-ARE pathway. J. Neural. Transm. Suppl. 2007, 72, 57-67. [CrossRef]

166. Matsubara, E.; Bryant-Thomas, T.; Quinto, J.P.; Henry, T.L.; Poeggeler, B.; Herbert, D.; Cruz-Sanchez, F.; Chyan, Y.J.; Smith, M.A.; Perry, G.; et al. Melatonin increases survival and inhibits oxidative and amyloid pathology in a transgenic model of Alzheimer's disease. J. Neurochem. 2003, 85, 1101-1108. [CrossRef] 
167. Ono, K.; Hirohata, M.; Yamada, M. Ferulic acid destabilizes preformed $\beta$-amyloid fibrils in vitro. Biochem. Biophys. Res. Commun. 2005, 336, 444-449. [CrossRef]

168. Hamaguchi, T.; Ono, K.; Murase, A.; Yamada, M. Phenolic compounds prevent Alzheimer's pathology through different effects on the amyloid- $\beta$ aggregation pathway. Am. J. Pathol. 2009, 175, 2557-2565. [CrossRef]

169. Cornejo, A.; Aguilar Sandoval, F.; Caballero, L.; Machuca, L.; Muñoz, P.; Caballero, J.; Perry, G.; Ardiles, A.; Areche, C.; Melo, F. Rosmarinic acid prevents fibrillization and diminishes vibrational modes associated to $\beta$ sheet in tau protein linked to Alzheimer's disease. J. Enzym. Inhib. Med. Chem. 2017, 32, 945-953. [CrossRef]

170. Rong, H.; Liang, Y.; Niu, Y. Rosmarinic acid attenuates $\beta$-amyloid-induced oxidative stress via Akt/GSK-3 $\beta /$ Fyn-mediated Nrf2 activation in PC12 cells. Free Radic. Biol. Med. 2018, 120, 114-123. [CrossRef] [PubMed]

171. Franco, R.; Casanovas, B.; Camps, J.; Navarro, G.; Martínez-Pinilla, E. Antixoxidant Supplements versus Health Benefits of Brief/Intermittent Exposure to Potentially Toxic Physical or Chemical Agents. Curr. Issues Mol. Biol. 2021, 43, 47. [CrossRef]

172. Cuttler, J.M. Application of Low Doses of Ionizing Radiation in Medical Therapies. Dose Response 2020, 18, 1559325819895739. [CrossRef] [PubMed]

173. Nakashima, H.; Ishihara, T.; Yokota, O.; Terada, S.; Trojanowski, J.Q.; Lee, V.M.Y.; Kuroda, S. Effects of $\alpha$-tocopherol on an animal model of tauopathies. Free Radic. Biol. Med. 2004, 37, 176-186. [CrossRef] [PubMed]

174. Murakami, K.; Murata, N.; Ozawa, Y.; Kinoshita, N.; Irie, K.; Shirasawa, T.; Shimizu, T. Vitamin C restores behavioral deficits and amyloid- $\beta$ oligomerization without affecting plaque formation in a mouse model of Alzheimer's disease. J. Alzheimers Dis. 2011, 26, 7-18. [CrossRef]

175. Das, B.; Dasgupta, S.; Ray, S. Potential therapeutic roles of retinoids for prevention of neuroinflammation and neurodegeneration in Alzheimer's disease. Neural. Regen. Res. 2019, 14, 1880-1892.

176. Yang, X.; Dai, G.; Li, G.; Yang, E.S. Coenzyme Q10 reduces $\beta$-amyloid plaque in an APP/PS1 transgenic mouse model of Alzheimer's disease. J. Mol. Neurosci. 2010, 41, 110-113. [CrossRef]

177. Dumont, M.; Kipiani, K.; Yu, F.; Wille, E.; Katz, M.; Calingasan, N.Y.; Gouras, G.K.; Lin, M.T.; Beal, M.F. Coenzyme Q10 decreases amyloid pathology and improves behavior in a transgenic mouse model of Alzheimer's disease. J. Alzheimer Dis. 2011, 27, 211-223. [CrossRef]

178. Mcmanus, M.J.; Murphy, M.P.; Franklin, J.L. The mitochondria-targeted antioxidant mitoq prevents loss of spatial memory retention and early neuropathology in a transgenic mouse model of Alzheimer's disease. J. Neurosci. 2011, 31, 15703-15715. [CrossRef]

179. Atitlán-Gil, A.; Bretón-De La Loza, M.M.; Jiménez-Ortega, J.C.; Belefant-Miller, H.; Betanzos-Cabrera, G. Activated and Micronized Zeolite in the Modulation of Cellular Oxidative Stress in Mexican Smokers: A Randomized Clinical Trial. Revista de Investigación Clínica 2017, 69, 146-151. [CrossRef]

180. Hira, S.; Saleem, U.; Anwar, F.; Sohail, M.F.; Raza, Z.; Ahmad, B. $\beta$-Carotene: A Natural Compound Improves Cognitive Impairment and Oxidative Stress in a Mouse Model of Streptozotocin-Induced Alzheimer's Disease. Biomolecules $2019,9,441$. [CrossRef]

181. Wang, P.; Su, C.; Li, R.; Wang, H.; Ren, Y.; Sun, H.; Yang, J.; Sun, J.; Shi, J.; Tian, J.; et al. Mechanisms and effects of curcumin on spatial learning and memory improvement in APPswe/PS1dE9 mice. J. Neurosci. Res. 2014, 92, 218-231. [CrossRef]

182. Handattu, S.P.; Monroe, C.E.; Nayyar, G.; Palgunachari, M.N.; Kadish, I.; Van Groen, T.; Anantharamaiah, G.M.; Garber, D.W. In vivo and in vitro effects of an apolipoprotein E mimetic peptide on amyloid- $\beta$ pathology. J. Alzheimer Dis. 2013, 36, 335-347. [CrossRef] [PubMed]

183. Clausen, A.; Bi, X.; Baudry, M. Effects of the superoxide dismutase/catalase mimetic EUK-207 in a mouse model of Alzheimer's disease: Protection against and interruption of progression of amyloid and tau pathology and cognitive decline. J. Alzheimer Dis. 2012, 30, 183-208. [CrossRef]

184. Chen, Y.Y.; Lian, D.; Lai, J.; Wu, Y.; Wang, L.; Chen, Y.Y.; Zhang, Y.; Boini, K.M.M.; Huang, Y.; Chen, Y.Y. Cathepsin B-Mediated NLRP3 Inflammasome Formation and Activation in Angiotensin II -Induced Hypertensive Mice: Role of Macrophage Digestion Dysfunction. Cell. Physiol. Biochem. 2018, 50, 1585-1600. [CrossRef]

185. Feng, Z.; Chang, Y.; Cheng, Y.; Zhang, B.L.; Qu, Z.W.; Qin, C.; Zhang, J.T. Melatonin alleviates behavioral deficits associated with apoptosis and cholinergic system dysfunction in the APP 695 transgenic mouse model of Alzheimer's disease. J. Pineal Res. 2004, 37, 129-136. [CrossRef]

186. Dragicevic, N.; Copes, N.; O’Neal-Moffitt, G.; Jin, J.; Buzzeo, R.; Mamcarz, M.; Tan, J.; Cao, C.; Olcese, J.M.; Arendash, G.W.; et al. Melatonin treatment restores mitochondrial function in Alzheimer's mice: A mitochondrial protective role of melatonin membrane receptor signaling. J. Pineal Res. 2011, 51, 75-86. [CrossRef]

187. Otalora, B.B.; Popovic, N.; Gambini, J.; Popovic, M.; Viña, J.; Bonet-Costa, V.; Reiter, R.J.; Camello, P.J.; Rol, M.Á.; Madrid, J.A. Circadian system functionality, hippocampal oxidative stress, and spatial memory in the APPswePS1dE9 transgenic model of Alzheimer disease: Effects of melatonin or ramelteon. Chronobiol. Int. 2012, 29, 822-834. [CrossRef]

188. Huang, Q.; Aluise, C.D.; Joshi, G.; Sultana, R.; Clair, S.D.K.; Markesbery, W.R.; Butterfield, D.A. Potential in vivo amelioration by N-Acetyl-L-cysteine of oxidative stress in brain in human double mutant APP/PS-1 knock-in mice: Toward therapeutic modulation of mild cognitive impairment. J. Neurosci. Res. 2010, 88, 2618-2629. [CrossRef] 